\title{
ZOÖLOGISCHE BIJDRAGEN TOT DE KENNIS DER KARAZEE. \\ (Nederlandsche Pool-Expeditie, 1882-83.)
}

I. Inleiding en algemeene mededeelingen.

DOOR

DR. J. MIAR. RUIJS. 
Zooals bekend, werd op het Internationaal Poolcongres, in Augustus 1881 te Petersburg gehouden, Dicksonhaven aan den mond van de Jenissei als het station aangewezen, dat Nederland, bij zijn deelneming aan het voorgenomen gemeenschappelijk onderzoek van het poolbekken zou bezetten.

De expeditie, die ik als natuurhistoricus vergezelde, verliet Amsterdam den 5 den Juli 1882, aan boord van het Noorsch schroefstoomschip »Varna«, dat haar naar de plaats van bestemming zou voeren. Zij kwam na een oponthoud van acht dagen te Trondhjem, den 22sten van dezelfde maand te Hammerfest aan en begon zes dagen later, in gezelschap van het stoomschip »Louise « van Bremen, haar eigenlijken tocht naar het Noorden.

Door den ongunstigen ijstoestand gelukte het eerst den 31sten Augustus door de Karische poort de Karazee binnen te dringen, waar de »Varna«, na herhaaldelijke insluiting, den 18den September in gezelschap van het den vorigen dag aangetroffen stoomschip 》Dymphna van Kopenhagen, voor goed in het pakijs invroor, terwijl de »Louise« het geluk had te ontsnappen en de terugreis naar Europa volbracht. De »Varna«, met haar geheele omgeving onafgebroken in drift, werd in den loop van den winter door ijspersing vernield en zonk zes maanden later, toen het ijs rondom haar zich opende, weg.

De waarnemingen en onderzoekingen der expeditie werden, toen de »Varna« verlaten was, vervolgd in en bij een op het ijs gebouwd houten huis, en voortgezet tot aan den $1^{\text {sten }}$ Augustus 1883. Op dien datum aanvaardde de Nederlandsche Expeditie, met zich voerende al de meteorelogische en andere resultaten, benevens het belangrijkst gedeelte der zoölogische verzameling en vergezeld van de Noorsche bemanning der »Varna«, met booten en sleden den terugtocht over het ijs. Allen hadden het geluk na een moeitevolle reis van 24 dagen de zuidpunt van het Waaigat, Kaap Grebeni te bereiken, waar zij, de stoomschepen »Louise« en »Nordenskjöld《 aantreffende, door deze werden opgenomen en verder naar Noorwegen werden teruggebracht.

Het grootste gedeelte der zoölogische collectie, dat aan boord van de $\gg$ Dymphna« was achtergelaten, kwam, doordat dit schip er in slaagde zich nit het ijs te bevrijden, een half jaar later ook in goede orde aall, zoodat al het door mij verzamelde materiaal is behouden gebleven.

Het Koninklijk Zoölogisch Genootschap »Natura Artis Magistra《 te Amsterdam, dat de kosten der zoölogische uitrusting op zich genomen had, werd eigenaar der geheele collectie, die, even als dit geschiedde met de verzamelingen, op de herhaalde reizen van de »Willem Barents« bijeengebracht, onder verschillende personen is verdeeld geworden, welke op zich namen ieder een gedeelte van het omvankrijk materiaal te bewerken.

De resultaten van dit onderzoek zullen in dit tijdschrift worden opgenomen. 


\section{Dreggereedschap, het dreggen onder het ijs, enz.}

Het materiaal tot verzamelen van zeedieren, waarover ik te beschikken had toen wij het vaderland verlieten, bestond uit drie dreggen, met een, daarbij behoorende, voldoende hoeveelheid lijn, 200 vademen; verder pelagische netten, schepnetten, enz. Van de dreggen was de grootste 70 bij 40 cM., terwijl het net $80 \mathrm{cM}$. diep was; van de beide kleinere dreggen had de eene, even als de grootste dreg, een rechthoekig raam, van de afimetingen 50 bij $25 \mathrm{cM}$., de andere een raam in den vorm van een cirkelsegment, waarvan koorde en pijl resp. 50 en $25 \mathrm{cM}$. lang waren; het net van beide was $55 \mathrm{cM}$. diep. De pelagische netten bestonden uit een aan twee zijden open trechtervormigen zak, van gaas vervaardigd; aan het wijde einde werd een hocpel van Spaansch riet, aan het nauwe een groote wijdmondsflesch bevestigd, en het geheel aan een stevig toiw gebonden, te water gelaten. Het gemakkelijkst was deze toestel van uit de vlet te gebruiken, terwijl deze door één man langzaam werd voortgeroeid.

Het is duidelijk, dat, zoolang wij met de 》Varma op reis en door de 》Louisa vergezeld waren, er niet zeer dikwijls gelegenheid tot dreggen enz. was, daar gewoonlijk de beweging der schepen, hoe langzaam somtijds ook, toch nog te snel was om te kunnen dreggen, en daar toch ook de reis hoofdzaak, zoölogisch onderzoek gedurende de reis daarentegen geheel en al bijzaak was, zoo sprak het van zelf, dat vooralsnog ter wille van den zoöloog niet kon worden afgeweken van datgene, wat noodig geoordeeld werd om ons zoo spoedig mogelijk tot ons doel te brengen, waarvan we toen nog niet wisten, dat we het nooit zouden bereiken. 'Toch was nu en dan de gelegenheid schoon, en met veel succes gebruikte ik, wanneer bv. het schip gedurende een half uur niet meer dan éénmijls vaart liep, de groote dreg.

'Toen wij na den $18^{\text {den }}$ September waren ingesloten en alle bewegingen van het schip onmogelijk geworden waren, moest naar een andere wijze van dreggen worden omgezien. De toestand van het ijs rondom ons, zooals die was, en nog veel meer, zooals die wa verloop van tijd werd, maakte het ten eencmale onmogelijk het middel toe te passen, dat door de Zweden in 1872-73 werd aangewend, gedurende hun overwintering op Spitsbergen, en waarvan ik tijdens den winter ook partij had kunnen trekken, wanneer wij te Dicksonshaven waren geweest.

Weldra bleek echter, dat ik tot een ander en veel eenvoudiger middel mijn toevlucht kon nemen. Zooals bekend, waren wij het geheele jaar door met het ons omringende pakijs in drift, en de snelheid, die het schip of het ijs ten opzichte van den bodem der zee verkreeg, was veelal groot genoeg, om van het slepen van de dreg eenig resultaat te verwachten. Ik had dus niets anders te doen dan de dreg te laten zakken in een der bijten bij de Varna, die toch steeds werden opengehouden, en zooveel lijn af te vieren, dat deze een schuinen stand ten opzichte van den bodem kon aannemen. De dreg, die, wanneer het schip zich langzaa.n in open water beweegt, gewoonlijk een kwartier of een half uur buiten wordt gelaten, eischte nu een langer verblijf op op den bodem der zee. Aanvankelijk nam ik hiervoor eenige uren, doch wanneer de drift niet zeer sterk was, bleek zulks niet voldoende te zijn; zoo ging ik er dan ten slotte toe over, om de dreg gedurende een of twee etmalen uit te laten. In vele gevallen evenwel, was de beweging 
zóó langzaam, dat zelfs znlk een tijjdsverloop geen resultaat opleverde en de dreg ledig boven kwam: Bovendien werd deze methode mij noodlottig, want toen in den nacht van 3 op 4 November bij de eerste groote ijspersing, die de $\gg$ Varna» aantastte, het ijs rondom het schip opbrak, werd ook de dreggelijn doorgesneden en ging met een der kleine dreggen verloren. De tweede kleine dreg volgde eenigen tijd later de eerste; rondom en onder het schip had de persing een waren chaos van ijsblokken gevormd, waartusschen de lijn waarschijnlijk vastraakte; ten minste nadat de toestel op den $15^{\text {den }}$ December op de gewone wijze was' afgevierd, was het den volgenden dag onmogelijk de laatste 10 vademen lijn en de dreg boven te krijgen; dagen lang werden elken morgen gedurende eenige uren pogingen daartoe aangewend, doch te vergeefs, en na de hevige werking van 24 December was natuurlijk het laatste spoor er van verdwenen. Met dezen datum sluit tevens de periode van het dreggen aan boord der $\gg$ Varna $\ll$ af, om opgevolgd te worden door een tweede, meer belangrijke, aanvangende met de voltooiing van het huis en onze vestiging op 》Nieuw-Holland $\ll$.

Op ongeveer 70 Meter afstand van het huis, aan de grens van onze schots en de omliggende, daarvan vroeger losgescheurde kleinere ijsbrokken, werd in het eenjarige ijs, dat laatstgenoemden onderling verbond, een vierkante bijt gehakt, waarvan de zijden ongeveer $1.25 \mathrm{M}$. lang waren.

Mijn materiaal om te dreggen was evenwel belangrijk geslonken, daar ik nog slechts de groote dreg en één lijn van ruim honderd vadem over had. Als een gevolg daarvan en ook van verschillende andere omstandigheden deden zich aanvankelijk ook allerlei bezwaren voor. De groote dreg bleek, wanneer wij slechts langzaam dreven, te zwaar te zijn, en te diep in den weeken zeebodem in te zinken. Zij kwam dan meestal boven bijna geheel gevuld met grijze leem, waaruit de bodem. gewoonlijk in hoofdzaak bestond, en nagenoeg zonder dieren. Het uitzoeken van deze massa moest, daar het gebruik der zeven, voor dit doel medegenomen, bij de heerschende koude tot aan de maand Juni een onmogelijkheid was, want alles bevroor bijna terstond tot één harde klomp, waarbij de dieren natuurlijk verloren gingen, binnenshuis geschieden; de modder werd op platte banken uitgespreid en moest met de hand of wel met staafjes, pincetten enz. onderzocht worden. Aan de uren arbeid, die ik hieraan besteden moest, was het resultaat gewoonlijk niet evenredig. Bij snelleren drift daarentegen werkte de dreg uitnemend en meer dan eenmaal kreeg ik 40 à 50 species bij één enkele dregging.

Veelal nam ik ook waar, dat de buit rijker was, wammeer tijdens de dregging de diepte af- dan wanneer zij toegenomen was, iets wat begrijpelijk wordt wamneer men zich den stand van dreg en dreggelijn ten opzichte van den bodem voorstelt.

Een geheel ander middel tot het vangen van dieren van den bodem, aanvankelijk gelijktijdig met de dreg, later herhaaldelijk uitsluitend aangewend, was het gebruiken van zwabbers. In het eerste geval werden cen of twee zwabbers op eenige vademen afstand voor elkander en vóór de dreg, aan de lijn bevestigd, voorzien van een gewicht van 5 à 10 kilo, dat hen op den bodem deed blijven. Bij het weglaten van de dreg werden aan een ijzeren, ongeveer $15 \mathrm{dM}$. lange staaf, vijf zwabbers op een onderling gelijken afstand bevestigd. Deze stang, aan beide uiteinden van een oog voorzien, was door middel van een zoogenaamden hanepoot aan de lijn bevestigd.

De zwabbers bewezen veel dienst, vooral voor het vangen van Echinodermen en Crustac eёn, maar gaven aanleiding, dat andere dieren, als b.v. Trochostoma boreale en groote wormen, in 't geheel niet werden gevangen. Men mag dus uit de vangsten, met de zwabbers uitshitend gedaan, volstrekt niet besluiten tot het ontbreken van bepaalde vormen op die plaats, waar de zwabbers werden gébruikt, noch, daar de eene vorm er veel gemakkelijker in bleef haken dan de andere, tot hun onderlinge verhouding in algemeenheid.

Wat ik betreurde, was het gemis van een kor, zooals die gewoonlijk op de $\gg$ Willem Barents $\ll$ gebruikt wordt. Waarschijnlijk zouden aan de Jenissei de dreggen voldoende zijn geweest, vandaar dat een kor niet onder mijn uitrusting voorkwam, maar bovendien zou bij het gemis van een stoomlier, een bij de niet al te groote werkkrachten, waarover we te beschikken hadden, het tel- 
kens ophalen van dezen zooveel zwaarderen toestel niet zonder bezwaar zijn geweest. Zooveel is zeker, dat hij hier met groot voordeel kon worden 'aangewend, zooals bleek uit de goede resultaten die de Heer Holm, de zoöloog van de Dymphna-expeditie, er mede verkreeg. Onder de gegeven omstandigheden overtrof hij alle audere werktuigen in bruikbaarheid.

Ik wil hier nog de aandacht vestigen op iets, dat misschien elders met groot voordeel kan worden aangewend. In het voorjaar, toen ik er in slaagde enkele vogels te verkrijgen, deed ik, na deze gevild te hebben, het overblijvende vleesch en verdere inwendige organen in een klein net met vrij groote mazen en hing dit op een diepte van 4 à 5 vademen in het water. Na verloop van enkele uren was de geheele massa als overdekt met een aantal Crustaceën, die bij onderzoek allen tot één zelfde species, namelijk A n on yx lag e n a, bleken te behooren. Hieruit laat zich afleiden, dat op de genoemde diepte òf geen andere dieren voorkomen, òf dat de genoemde diersoort er in slaagde alle andere mededingers te verjagen. Tot mijn spijt ontbrak mij het materiaal om deze proeven ook voor verschillende diepten te herhalen, maar, zooals gezegd, kan deze methode misschien met veel succes $b \ddot{j}$ andere gelegenheden worden toegepast.

'Tot een zoologisch onderzoek van de oppervlakte der zee, door middel van het pelagisch net, was gedurende de reis slechts zeer enkele keeren en tijdens de insluiting in het ijs in 't geheel geen gelegenheid, daar gebrek an voldoende open water mij belétte iets met dezen toestel uit te richten.

\section{Het conserveeren der dieren.}

Voor het bewaren der verzamelde voorwerpen werd in den regel door mij aethyl-alcohol gebruikt van een sterkte afwisselend tusschen 60 en $70 \%$. Voor bizonder weeke organismen, als kwallen enz., wendde ik wel een $2 \%$ oplossing van Bichromas Kalicus aan, daarbij zorg dragende, dat tot 3 of 4 malen toe, telkens on de twee dagen de oplossing ververscht werd.

De preparaten werden ingesloten: $1^{\lrcorner}$in vierkante blikken bussen, die na vulling werden dichtgesoldeerd; $2^{\circ}$ in glazen buisjes van zeer verschillende afmetingen; $3^{\circ}$ in glazen stopflesschen, en $4^{\prime}$ in met kurken gesloten wijdmondsflesschen, waarvoor dezulke, die voor het conserveeren van zoogenaamde mixed pickles en ander zuur gebruikt worden, een groote geschiktheid bezitten.

De blikken bussen zijn volgens mijn ondervinding niet zeer aan te bevelen; behalve, dat zij het nadeel geven, dat men de dieren niet blijft zien en zich dus niet kan overtuigen of ze in goeden toestand verkeeren, zonder het dichtgesoldeerde blik te openen en daardoor gewoonlijk onbruikbaar te maken, zijn ze toch alléén maar geschikt om groote dieren te bewaren, daar men van kleinere om het blik te vullen, een te groot aantal op elkaar moet pakken, hetgeen een zeer groot bezwaar bij het conserveeren is. In mijn geval vond ik ze alleen voor vrij groote Echimodermen, Asterophython eucnemis, Cibrella sanguinolentus, Archastertenuispinus, enz. misschien niet ongeschikt, daar deze weinig lichaamsvocht bevatten en dus gemakkelijk zijn te conserveeren, maar over 't algemeen had ik mijn blikken bussen gaarne vervangen gezien door dikwandige cylinderglazen van verschillende wijdten gesloten door vastgelakte glazen platen, door een zelfcle inrichting dus, als men op musea heeft, om vele voorwerpen in ten toon te stellen. Deze cylinderglazen zijn zeker belangrijk duiurder, maar de voordeelen, die zij aanbieden boven de insluiting in blik, wegen m. i. wel tegen wat hoogeren prijs op.

Glazen buisjes, mits de kurken goed sluitend zijn te maken, zijn voor kleinere dieren zeer aan te bevelen; de mijne hadden nast het voordeel, dat ze bizonder sterk waren, het nadeel, dat ze, met een bolvormige vlakte eindigende, niet konden staan, tenzij zij in een rek of op andere wijze ondersteund werden vastgezet; men zou ze kunnen vervangen door buisjes met een vlakken bodem of wel door wijdmondsflesschjes van gelijke grootte en inhoud. 
Het geschiktst in 't gebruik kwamen mij de straksgenoemde picklesflesschen voor, die wel gewoonlijk niet sierlijk zijn, maar wat grootte, vorm en sterkte aangaat, in omstandigheden, als de

onze, voor voorloopige verpakking en transport uitstekend aan het doel beantwoorden. De uitrusting onzer expeditie bracht mede, dat ik over een vrij groot aantal te beschikken had.

\section{Plaats van onderzoek, aantal dreggingen, enz.}

Van al de dreggingen, die ik kon doen, waren er ten Westen van Nova-Zembla slechts twee van eenige beteekenis, één ten $Z$. van het eiland Mezdusharsky en één onder den wal van Waaigat. Al de overigen vonden plaats in het zuidelijk, voornamelijk in het zuidoostelijk gedeelte der Karazee, wanneer men dezen naam toepast op dat gedeelte der $1 \mathrm{~J}_{\text {szee, }}$ dat begrensd wordt door de Russische kust, de Oostkust van Nova-Zembla, den meridiaan van $70^{\circ}$ lengte en de kust van het Schiereiland Jalmal, terwijl men de oostelijke voortzetting dezer zee als de eigenlijke Siberische IJ szee beschouwt.

Van het totaal aantal dreggingen, in de Karazee volbracht, dat 81 bedraagt, is de noordelijkste en tegelijk onstelijkste geweest op $71^{\circ} 44^{\prime} \mathrm{N}$. B. en $65^{\circ} 25^{\prime}$ O. L., de zuidelijkste op $69^{\circ} 55^{\prime} \mathrm{N}$. B. en $64^{\circ}$ O. L., de westelijkste op $70^{\circ} 15^{\prime} \mathrm{N}$. B. en $60^{\circ} 25^{\prime}$ O. L.

De dreggingen $1-7$ waren geïsoleerd, vonden bij vrij gruote tusschenruimten plaats, de overige 76 daarentegen volgden elkander bij tusschenpoozen van één of weinige dagen op, en daar wij gedurende den tijd, waarin ze gedaan werden, slechts in drift waren en dus de verplaatsing een betrekkelijk zeer geringe was, zoo is het duidelijk, dat de stations alle zeer dicht op elkander gedrongen zijn. Een kaart, die ze alle met nawwkeurigheid aangaf, zon op zeer groote schaal moeten zijn.

Om zich echter voor te stellen, welke plaats deze groep van 76 stations in de Karazee inneemt, denke men zich een driehoek met een stompen hoek van $\pm 105^{\circ}$; van dien driehoek ligt de top op $71^{\circ} 55^{\prime} \mathrm{N}$. B en $65^{\circ} 38^{\prime} \mathrm{O}$. L., het hoekpunt van den stompen hoek op $70^{\circ} 57^{\prime} \mathrm{N}$. B. en $64,2 S^{\prime}$ O. L. en het derde hoekpunt op $71^{\circ} 6^{\prime} \mathrm{N}$. B. en $62^{\circ} 28^{\prime}$ O. L. ; binnen dezen driehoek zijn al de bedoelde stations gelegen.

'Tevens wil ik hier doen opmerken, dat binnen dit, door mij onderzocht, gebied vroeger slechts op drie punten werd gedregd en wel in 1875 door de Zweedsche expeditie op $71^{\circ} 5^{\prime} \mathrm{N}^{\mathrm{B}} \mathrm{B}$. en $63^{\circ} .20^{\prime}$ O. L. en dus het dichtst bij mijn station 74 , dat op $71^{\circ} 6^{\prime} \mathrm{N}$. B. en $63^{\circ} 16^{\prime} \mathrm{O}$. L. ligt, en in 1876 door de Vega-expeditie op $71^{\circ} 3^{\prime} \mathrm{N}$. B. en $63^{\circ} 46^{\prime} \mathrm{O}$. L., en op $71^{\prime} 21^{\prime} \mathrm{N}$. B. $64^{\prime} 53^{\prime} \mathrm{O}$. L., die het dichtst vallen resp. bij mijn stations 15 en 24 , welke op $71^{\circ} 1^{\prime} \mathrm{N}$. B. 63 , $57^{\prime}$ O. L. $71^{\circ} 20^{\prime}$ N. B. en $64^{\circ} 54^{\prime}$ O. L. zijn gelegen.

In de hier volgende tabel is de plaats van elk station aangegeven met een nauwkeurigheid, voor zoover die onder onze omstandigheden mogelijk was. 
Tabellarisch Overzicht der

\begin{tabular}{|c|c|c|c|c|c|c|c|c|}
\hline \multirow{2}{*}{$\begin{array}{l}\dot{a} \\
\stackrel{0}{0} \\
\stackrel{+}{+} \\
\pm \\
\pm \\
\pm 2\end{array}$} & \multirow{2}{*}{\multicolumn{2}{|c|}{$\mathrm{D}, \mathrm{a}$ t $\mathrm{u} \mathrm{m}$. }} & \multicolumn{2}{|c|}{ P l a a t s. } & \multirow{2}{*}{ 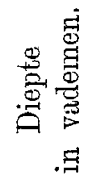 } & \multirow{2}{*}{ Gesteldheid van den bodem. } & \multicolumn{2}{|c|}{ Water a/d oppervl. } \\
\hline & & & N. Br. & o. L. v. Gr. & & & Temp. & Dens. \\
\hline 1 & $8 / \mathrm{VIII}$ & '82 & $70^{\circ} \quad 29^{\prime}$ & $52^{\circ} 48^{\prime}$ & 70 & zand met steenen. & - & - \\
\hline 2 & $16 /$ VIII & 82 & $69^{\circ} 5 \dot{3}^{\prime}$ & $58^{\circ} 54^{\prime}$ & 43 & leem gemengd met zand. & $+2 \circ .3$ & 1008.5 \\
\hline 3 & $1 / \mathrm{IX}$ & '82 & $70^{\circ} 15^{\prime}$ & $60^{\circ} \quad 25^{\prime}$ & 108 & bruin leem. & $+0^{\circ} .6$ & 1009 \\
\hline 4 & $15 / \mathrm{IX}$ & '82 & $69^{\circ} 55^{\prime}$ & $64^{\circ} \quad 0^{\prime}$ & 18 & steenen? & $-0^{\circ} .7$ & 1016 \\
\hline 5 & $27 / \mathrm{IX}$ & '82 & $70^{\circ} \quad 8^{\prime}$ & $64^{\circ} \quad 6^{\prime}$ & 62 & grauw leem. & -0.8 & 1013.3 \\
\hline 6 & 3/XI & 's2 & $0^{\circ} 13^{\prime}$ & & 81 & $\gg$ & - & - \\
\hline 7 & $4 / \mathrm{XI}$ & '82 & $70^{\circ} 13^{\prime}$ & & - & - & - & - \\
\hline 8 & $24 / \mathrm{I}$ & '83 & $70^{\circ} 57^{\prime}$ & $64^{\circ} \cdot 5^{\prime}$ & 65 & taai grijjs leem. & - & - \\
\hline 9 & $26 / 1$ & '83 & $71^{\circ} \quad 0^{\prime}$ & $64=17^{\prime}$ & 61 & grijze leem met eene bruine laag bedekt. & - & - \\
\hline 10 & $29 / \mathrm{I}$ & '83 & $71^{\circ} \quad 3^{\prime}$ & $64^{\circ} 34^{\prime}$ & 58 & bruine modder. & - & - \\
\hline 11 & $31 / \mathrm{I}$ & '83 & $71^{\circ} \quad 4^{\prime}$ & $64^{\circ} 34^{\prime}$ & 55 & grijs leem. & -10.5 & - \\
\hline 12 & $2 / \mathrm{II}$ & 83 & $71^{\circ} \quad 4^{\prime}$ & $64^{\circ} 20^{\prime}$ & 60 & $\gg$ & $-2^{\circ} .0$ & 1024.0 \\
\hline 13 & $6 / \mathrm{II}$ & $' 83$ & $71^{\circ} \quad 3 \prime$ & $64^{\circ} \quad 1^{\prime}$ & 60 & grijs leem met bruine bovenlaag. & $-1^{\circ} .8$ & 1022.0 \\
\hline 14 & $8 / \mathrm{II}$ & '83 & $71^{\circ} \quad 1^{\prime}$ & $64^{\circ} \quad 0^{\prime}$ & 58 & grijze leemklompen en dunne bruine modder. & $-1^{\circ} .5$ & 1021.0 \\
\hline 15 & $10 / \mathrm{II}$ & ’83 & $71^{\circ} \quad 1^{\prime}$ & $63^{\circ} 57^{\prime}$ & 60 & grijs leem en bruine modder. & $-1^{\circ} .6$ & 1022.0 \\
\hline 16 & $12 / \mathrm{II}$ & '83 & $71^{\circ} \quad 2^{\prime}$ & $64^{\circ} \quad 0^{\prime}$ & $58 \frac{1}{2}$ & grijze leemklompen en dunne bruine modder. & $-1^{\circ} .5$ & 1020.0 \\
\hline 17 & $13 / \mathrm{II}$ & '83 & $71^{\circ} \quad 3^{\prime}$ & $64^{\circ} \quad 3^{\prime}$ & $54 \frac{1}{2}$ & $\gg$ & $-1^{\circ} .4$ & 1023.0 \\
\hline 18 & $14 / \mathrm{II}$ & '83 & $71^{\circ} \quad 4^{\prime}$ & $64^{\circ} .5^{\prime}$ & 55 & - & -1.5 & 1021.5 \\
\hline 19 & $16 / \mathrm{II}$ & '83 & $71^{\circ} \quad 5^{\prime}$ & $64.7 \prime$ & 54 & taai grijs leem met dunne bruine modder overdekt. & $-1^{\circ} .6$ & 1022.5 \\
\hline 20 & $20 / \mathrm{II}$ & 83 & $71^{\circ} \quad 8^{\prime}$ & $64^{\circ} 27^{\prime}$ & 51 & $\gg$ & $-1^{\circ} .7$ & 1022.0 \\
\hline 21 & $22 / \mathrm{II}$ & '83 & $71^{\circ} 10^{\prime}$ & $64035^{\prime}$ & $52 \frac{1}{2}$ & leem met eenig zand. & $-1^{\circ} .5$ & 1021.5 \\
\hline 22 & $24 / \mathrm{II}$ & '83 & $71^{\circ} 13^{\prime}$ & $64 \circ 43^{\prime}$ & $59 \frac{1}{2}$ & bruine modder en zand. & $-1^{\circ} .6$ & 1021.0 \\
\hline 23 & $26 / \mathrm{II}$ & '83 & $71^{\circ} 17$ & $64 \circ 50^{\prime}$ & $66 \frac{1}{2}$ & grijs leem met eenig zand. & $-1^{\circ} .4$ & 1020.5 \\
\hline 24 & $27 / \mathrm{II}$ & '83 & $71^{\circ} 20^{\prime}$ & $64^{\circ} 54^{\prime}$ & 77 & leem met sporen van zand. & $-1^{\circ} .5$ & 1020.0 \\
\hline 25 & $1 / \mathrm{III}$ & 83 & $71^{\circ} 20^{\prime}$ & $64^{\circ} .53^{\prime}$ & 68 & grijs taai leem met bruine bovenlaag. & $-1^{\circ} .4$ & 1022.5 \\
\hline 26 & $3 / \mathrm{III}$ & 83. & $71^{\circ} 30^{\prime}$ & $65^{\circ} \quad 4^{\prime}$ & 88 & $\gg$ & $-1^{\circ} .4$ & 1021.5 \\
\hline 27 & $5 / \mathrm{III}$ & '83 & $71^{\circ} 37^{\prime}$ & $65^{\circ} \quad 7^{\prime}$ & 83 & grijsblauw leem met bruine bovenlaag. & -10.4 & 1021.0 \\
\hline $2 S$ & $6 / \mathrm{III}$ & '83 & $71^{\circ} 38^{\prime}$ & $65^{\circ} 11^{\prime}$ & $84 \frac{1}{2}$ & $\gg$ & -10.5 & 1020.5 \\
\hline 29 & $8 / \mathrm{III}$ & '83. & $71^{\circ} 36^{\prime}$ & $65^{\circ} \quad 3^{\prime}$ & $75 \frac{1}{2}$ & grauw leem. & $-1^{\circ} .4$ & 1020.0 \\
\hline 30 & $10 / \mathrm{III}$ & '83 & $71^{3} 36^{\prime}$ & $64^{\circ} 54^{\prime}$ & 76 & dumne bruine modder. & -0.8 & 1020.0 \\
\hline 81 & $12 / \mathrm{III}$ & '83 & $71^{\circ} 40^{\prime}$ & $64^{\circ} 49$ & 66 & grijs leem met bruine bovenlaag. & -1.5 & 1019.0 \\
\hline 32 & $15 / \mathrm{III}$ & '83 & $71^{\circ} 40^{\prime}$ & $64^{\circ} 53^{\prime}$ & $74 \frac{1}{2}$ & $\gg$ & $-1^{\circ} .4$ & 1020.5 \\
\hline 33 & $17 / \mathrm{III}$ & '83 & $71^{\circ} 39^{\prime}$ & $64^{\circ} 42^{\prime}$ & $68 \frac{1}{2}$ & $\gg$ & $-1 \% .4$ & 1021.0 \\
\hline 34 & $19 / \mathrm{III}$ & '83 & $71^{\circ} 34^{\prime}$ & $64^{\circ} 38^{\prime}$ & 60 & $\gg$ & $-1^{\circ} .4$ & 1021.0 \\
\hline 35 & $22 /$ III & '83 & $71^{\circ} 33^{\prime}$ & $64^{\circ} 36^{\prime}$ & 60 & $\gg$ & $-1^{\circ} .4$ & 1022.0 \\
\hline 36 & $24 / \mathrm{III}$ & '83 & $71^{\circ} 32^{\prime}$ & $64^{\circ} 37^{\prime}$ & 55 & . & -1.5 & 1021.0 \\
\hline 37 & $27 /$ III & '83 & $71^{\circ} 33^{\prime}$ & $64^{\circ} 43^{\prime}$ & 54 & dikke leemklompen met bruine bovenlaag. & $-1^{\circ} .5$ & 1021.0 \\
\hline 38 & $29 / \mathrm{III}$ & '83 & $71^{\circ} 33^{\prime}$ & $64^{\circ} \cdot 45^{\prime}$ & $58 \frac{1}{2}$ & dumne bruine modder. & $-1 \cdot .4$ & 1021.5 \\
\hline 39 & 31/III & '83 & $71^{\circ} 33^{\prime}$ & $64^{\circ} 47^{\prime}$ & 61 & $\gg \quad: \quad \cdot$ & $-0^{\circ} .0$ & 1020.0 \\
\hline 40 & $2 / \mathrm{IV}$ & '83 & $71^{\circ} 29^{\prime}$ & $64^{\circ} 52^{\prime}$ & $55 \frac{1}{2}$ & $\gg$ & $-1^{\circ} .4$ & 1021.0 \\
\hline
\end{tabular}




\section{verschillende Dreggingen.}

\begin{tabular}{|c|c|c|c|c|c|}
\hline \multicolumn{2}{|c|}{ Water a/d bodem. } & \multirow{2}{*}{$\begin{array}{l}\mathrm{D} \text { u } \mathrm{u} r \\
\quad \text { in } \\
\text { u } \mathrm{r} \text { e } \mathrm{n}\end{array}$} & \multirow{2}{*}{ 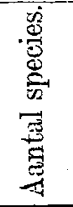 } & \multirow{2}{*}{ Dreggereedschap. } & \multirow{2}{*}{ Aanmerkingen. } \\
\hline Temp. & Dens. & & & & \\
\hline- & - & $\frac{1}{2}$ nur & 38 & groote dreg. & \\
\hline$-1^{\circ} .5$ & 1026.0 & $\frac{1}{2}$ uur & 30 & $\gg$ & \\
\hline$-1^{\circ} .0$ & 1026.2 & $\frac{1}{2}$ uur & 10 & $\gg$ & de dreg kwam onklaar boven. \\
\hline$-1^{\circ} .2$ & 1023.0 & $\frac{1}{2}$ uur & 0 & $\begin{array}{l}\gg \\
\cdots\end{array}$ & $\begin{array}{l}\text { het net geheel verscheurd, waarschijnlijk door } \\
\text { steenen op den bodem. }\end{array}$ \\
\hline-1.8 & 1026.2 & $\frac{1}{2}$ uur & 14 & kleine dreg. & wormkokers in zeer groote menigte. \\
\hline- & - & 24 uur & 4 & $\gg$ & de drift was zeer gering geweest. \\
\hline- & - & - & - & & dreggelijn door het ijs doorgesneden. \\
\hline- & - & 21 uur & 4 & groote dreg en 1 zwabber. & . \\
\hline- & - & 47 uur & 16 & $\gg$ & \\
\hline- & - & 72 uur & 26 & $\gg$ & \\
\hline$-0^{\prime} .8$ & - & & 11 & $\gg$ & talrijke halfvergane wormkokers en schelpen. \\
\hline$-1^{\circ} .4$ & 1026.0 & & 9 & : $\gg$ & $\begin{array}{l}\text { de zwabber was geheel ledig, denkelijk door } \\
\text { het niet raken van den bodem. }\end{array}$ \\
\hline$-1^{\circ} .8$ & 1025.0 & & 7 & groote dreg en 2 zwàbbers. & \\
\hline$-1^{\circ} .0$ & 1026.0 & & 13 & groote dreg en 1 zwabber. & enkele steenen. \\
\hline$-1^{\circ} .6$ & 1024.0 & & 17 & $\gg$ & \\
\hline$-0^{\circ} .6$ & 1023.0 & & 13 & $\gg$ & \\
\hline$+0^{\circ} .1$ & 1023.0 & & 24 & $\gg$ & enkele groote, platte moerasertsstukken. \\
\hline$-1^{\circ} .2$ & 1024.0 & & 6 & 〉 & dreg onklaar. \\
\hline$-1^{\circ} .0$ & 1025.0 & 43 uur & 19 & $\gg$ & fragmenten van een Floridee. \\
\hline$-0^{\circ} .6$ & 1024.5 & & 22 & $\gg$ & \\
\hline$-0^{\prime} .6$ & - & & 21 & $\gg$ & ontzaggelijk aantal wormkokers. \\
\hline-1.0 & 1024.0 & & 25 & $\gg$ & \\
\hline$-0^{\circ} .6$ & 1024.0 & & 25 & $\gg$ & \\
\hline$-0^{\circ} .6$ & 1025 & $23 \cdot \operatorname{uur}$ & 30 & vijf zwabbers. & \\
\hline$-0^{5} .8$ & 1024.5 & & 23 & $\gg$ & \\
\hline$-0^{\prime} .2$ & 1025.0 & & 29 & $\gg$ & \\
\hline$+0^{3} .3$ & 1024.0 & & 25 & groote dreg. & zeer veel wormkokers. \\
\hline$-1^{2} .0$ & 1025.0 & & 21 & vijf zwabbers. & \\
\hline$-1^{\circ} .0$ & 1025.0 & & 12 & $\gg$ & \\
\hline$-1^{\circ} .4$ & 1025.0 & & 7 & groote dreg. & eenige Florideën. \\
\hline- & - & & 19 & vijf zwabbers. & kogelvormige moerasertsstukken, eenige Florideën \\
\hline$-1^{\circ} .3$ & 1025.0 & $45 \frac{1}{2}$ unr & $\begin{array}{l}18 \\
14\end{array}$ & $\stackrel{ }{\gg}$ groote dreg en 1 zwabber. & talrijke wormkokers. \\
\hline$-\overline{0} .6$ & $-\overline{-}$ & & $\begin{array}{l}14 \\
23\end{array}$ & $\begin{array}{l}\text { groote dreg en } 1 \text { zwabber. } \\
\text { vijf zwabbers. }\end{array}$ & vele wormkokers, eenige Florideën. \\
\hline$-1^{\circ} .8$ & 1026.0 & & 16 & $\gg$ & \\
\hline$-1^{\circ} .3$ & 1025.5 & 24 uur & 22 & $\gg$ & \\
\hline$\therefore-$ & - & $66 \mathrm{uur}$ & 27 & groote dreg en 1 zwabber. & \\
\hline$-0^{\circ} .0$ & 1025.0 & 24 uur & 32 & vijf zwabbers. & \\
\hline$-1^{\circ} .4$ & 1025.0 & 28 uur & 33 & $\gg$ & \\
\hline$-1^{\circ} .8$ & 1025.0 & 24 uur & 21 & $\gg$ & \\
\hline
\end{tabular}




\begin{tabular}{|c|c|c|c|c|c|c|c|c|}
\hline \multirow{2}{*}{ 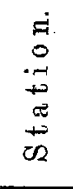 } & \multirow{2}{*}{\multicolumn{2}{|c|}{ D a-t u m. }} & \multicolumn{2}{|c|}{ P I a a ts, } & \multirow{2}{*}{ 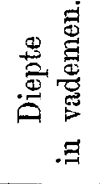 } & \multirow{2}{*}{ Gesteldheid van den bodem. } & \multicolumn{2}{|c|}{ Water a/d opperrl. } \\
\hline & & & N. Br. & O. L, v. G. & & & Temp. & Dens. \\
\hline 41 & $5 / \mathrm{IV}$ & '83 & $71^{\circ} 30^{\prime}$ & $64^{\circ} 38^{\prime}$ & 55 & dunne bruine modder. & $-1^{\circ} .4$ & 1021.0 \\
\hline 42 & $9 / \mathrm{IV}$ & '83 & $71^{\circ} 33^{\prime}$ & $64^{\circ} 48^{\prime}$ & 55 & $\gg$ & $-0^{0} .4$ & 1021.0 \\
\hline 43 & $11 / \mathrm{IV}$ & '83 & $71^{\circ} 36^{\prime}$ & $64^{\circ} 58^{\prime}$ & $67 \frac{1}{2}$ & $\gg$ & -0.9 & $1019.0^{\circ}$ \\
\hline 44 & $13 / \mathrm{IV}$ & '83 & $71^{\circ} 41^{\prime}$ & $65^{\circ} 8^{\prime}$ & $72^{2}$ & $\gg$ & -0.3 & 1020.5 \\
\hline 45 & $14 / \mathrm{IV}$ & '88 & $71^{\circ} 43^{\prime}$ & $65^{\circ} 13^{\prime}$ & 82 & $\gg$ & $-1^{\circ} .8$ & 1021.0 \\
\hline 46 & $16 / \mathrm{IV}$ & '83 & $71^{\circ} 44^{\prime}$ & $65^{\circ} 25^{\prime}$ & 88 & $\gg$ & -1.4 & 1020.0 \\
\hline 47 & $20 / \mathrm{IV}$ & '83 & $71^{\circ} 42^{\prime}$ & $65 \cdot 10^{\prime}$ & 87 & $\gg$ & -10.4 & 1021.0 \\
\hline 48 & $23 / \mathrm{IV}$ & '88 & $71^{\circ} 39^{\prime}$ & $64^{\circ} 58^{\prime}$ & 78 & $\gg$ & -10.3 & 1020.0 \\
\hline 49 & $27 / \mathrm{IV}$ & '83 & $71^{\circ} 35^{\prime}$ & $64^{\circ} 49^{\prime \prime}$ & 69 & $\gg$ & $-1^{\circ} .6$ & 1021.0 \\
\hline 50 & $29 / \mathrm{IV}$ & '83 & $71^{\circ} 38^{\prime}$ & $64^{\circ} 52^{\prime}$ & 50 & grijs leem met bruin vermengd. & $-1^{\circ} .4$ & 1022.0 \\
\hline 51 & $4 / \mathrm{V}$ & '83 & $71^{\circ} 31^{\prime}$ & $64^{\circ} 13^{\prime}$ & 47 & bruine modder. & $-1^{3} .4$ & 1019.5 \\
\hline 52 & $5 / \mathrm{V}$ & '83 & $71 \cdot 33^{\prime}$ & $64^{\circ} 14^{\prime}$ & 44 & $\gg$ & $-1^{\circ} .4$ & - \\
\hline 53 & $7 / \mathrm{V}$ & '88 & $71^{\circ} 31^{\prime}$ & $64^{\circ} 16^{\prime}$ & 49 & bruine modder. & -1.4 & 1021.0 \\
\hline 54 & $10 / \mathrm{V}$ & '88 & $71^{\circ} 29^{\prime}$ & $64^{\circ} 17^{\prime}$ & 51 & $\gg$ & -1.4 & 1022.5 \\
\hline 55 & $12 / \mathrm{V}$ & '83 & $71 \cdot 28^{\prime}$ & $64^{\circ} 17 \prime$ & $51 \frac{1}{2}$ & $\gg$ & -10.4 & 1020.0 \\
\hline 56 & $15 / \mathrm{V}$ & '83 & $71^{\circ} 25^{\prime}$ & $64^{\circ} 16^{\prime}$ & 51 & grijs leem met dunne bruine bovenlaag. & - & -1 \\
\hline 57 & $17 / \mathrm{V}$ & '83 & $71^{\circ} 22^{\prime}$ & $64^{\prime} 17^{\prime}$ & 70 & bruine modder. & $-1^{\circ} .4$ & 1021.0 \\
\hline 58 & $21 / \mathrm{V}$ & '83 & $71^{\circ} 23^{\prime}$ & $64^{\circ} 13^{\prime}$ & 70 & grijs leem met bruine bovenlaag. & $-1^{\circ} .4$ & 1021.5 \\
\hline 59 & $23 / \mathrm{V}$ & '83 & $71^{\circ} 25^{\prime}$ & $64^{\circ} \quad 9^{\prime}$ & 50 & $\gg$ & $-1^{\circ} .4$ & 1022.0 \\
\hline 60 & $26 / \mathrm{V}$ & '83 & $71^{\circ} 19^{\prime}$ & $64^{\circ} \quad 3^{\prime}$ & 56 & $\gg$ & $-1^{\circ} .4$ & 1020.5 \\
\hline 61 & $29 / \mathrm{V}$ & '83 & $71^{\circ} 20^{\prime}$ & $63^{\circ} 57^{\prime}$ & 55 & $\gg$ & $-1 . .4$ & 1022.0 \\
\hline 62 & $1 / \mathrm{VI}$ & '83 & $71^{\circ} 19^{\prime}$ & $63^{\circ} 56^{\prime}$ & 57 & $\gg$ & $-1^{\circ} .1$ & 1020.0 \\
\hline 63 & $4 / \mathrm{VI}$ & '83 & $71^{\circ} 17^{\prime}$ & $64^{\circ} \quad 6^{\prime}$ & 56 & $\gg$ & $+0^{\circ} .8$ & 1016.0 \\
\hline 64 & $7 / \mathrm{VI}$ & 83 & $71 \cdot 17^{\prime}$ & $64^{\circ} 6^{\prime}$ & 61 & bruine modder. & +0.6 & 1001.0 \\
\hline 65 & $9 / \mathrm{VI}$ & '83 & $71^{\circ} \cdot 16^{\prime}$ & $64^{\circ} \quad 8^{\prime}$ & 77 & grijs leem. ' & +0.5 & 1001.0 \\
\hline 66 & $12 / \mathrm{VI}$ & '83 & $71^{\circ} 12^{\prime}$ & $64^{\circ} \quad 6^{\prime}$ & 55 & bruine modder. & +0.4 & 1001.0 \\
\hline 67 & $15 / \mathrm{VI}$ & '83 & $71^{\circ} 13^{\prime}$ & $64^{\circ} 15^{\prime}$ & 59 & $\gg$ & +0.4 & 1001.0 \\
\hline 68 & $18 / \mathrm{VI}$ & '83 & $71^{\circ} 18^{\prime}$ & $68^{\prime} 31^{\prime}$ & 75 & grijs leem en bruine bovenlaag. & $+0^{3} .4$ & 1001.0 \\
\hline 69 & $19 / \mathrm{VI}$ & '83 & $71^{\circ} 19^{\prime}$ & $63^{\circ} 34^{\prime}$ & 66 & grijs leem. & $+0^{0} .4$ & 1001.0 \\
\hline 70 & $20 / \mathrm{VI}$ & '83 & $71^{\circ} 20^{\prime}$ & $63^{\prime} 38^{\prime}$ & 75 & grijs leem met bruine bovenlaag. & $+0^{3} .7$ & 1001.0 \\
\hline 71 & $23 / \mathrm{VI}$ & '88 & $71^{\circ} 19^{\prime}$ & $63^{\circ} 36^{\prime}$ & 85 & blauwgrijss leem. & $+0^{0} .7$ & 1001.0 \\
\hline 72 & $25 / \mathrm{VI}$ & 88 & $71 \cdot 15^{\prime}$ & $63^{\circ} 36^{\prime}$ & 94 & bruine modder. & +0.8 & 1001.0 \\
\hline 73 & $30 / \mathrm{VI}$ & '83 & $71^{\circ} 12^{\prime}$ & $63^{\prime} 36^{\prime}$ & $76 \frac{1}{2}$ & $\gg$ & +0.6 & 1001.0 \\
\hline 74 & $3 / \mathrm{VII}$ & '83 & $71^{\circ} \quad 6^{\prime}$ & $63^{\circ} 16^{\prime}$ & 70 & $\gg$ & +0.6 & 1001.0 \\
\hline 75 & $6 / \mathrm{VII}$ & '83 & $\begin{array}{ll}71^{\circ} & 6^{\prime}\end{array}$ & $63^{\prime} \quad 4^{\prime}$ & 76 & $\gg$ & $+0^{3} .6$ & 1001.0 \\
\hline 76 & $10 / \mathrm{VII}$ & '83 & $71^{\circ} \quad 4^{\prime}$ & $62^{\prime} 52^{\prime}$ & $78 \frac{1}{2}$ & $\gg$ & $+0^{3} .9$ & 1001.0 \\
\hline 77 & $12 / \mathrm{VII}$ & '83 & $71^{\circ} 4^{\prime}$ & $62^{\circ} \cdot 43^{\prime}$ & 76 & $\gg$ & $+1^{\circ} .2$ & 1001.0 \\
\hline 78 & $16 / \mathrm{VII}$ & '83 & $71^{\circ} \quad 5 \prime$ & $62^{\circ} 42^{\prime}$ & 76 & blauwgrijs leem. & $+1^{\circ} .2$ & 1001.0 \\
\hline 79 & $18 / \mathrm{VII}$ & '83 & $71^{\circ} \quad 4^{\prime}$ & $62^{\circ} 45^{\prime}$ & 77 & bruine modder. & $+1^{\circ} .1$ & 1001.0 \\
\hline 80 & $20 / \mathrm{VII}$ & '83 & $71^{\circ} \quad 6^{\prime}$ & $62 \circ 48^{\prime}$ & $75 \frac{1}{2}$ & grijs leem met bruine bovenlaag. & $+1^{\circ} .1$ & 1001.0 \\
\hline 81 & $23 / \mathrm{VII}$ & '83 & $71^{\circ} \quad 5^{\prime}$ & $62^{\circ} 52^{\prime}$ & 73 & bruine modder. & $+1^{\circ} .3$ & 1001.0 \\
\hline 82 & $26 / \mathrm{VII}$ & '83 & $71^{\circ} 5^{\prime}$ & $62^{\circ} 45 !$ & $73 \frac{1}{2}$ & i» & $+1^{\circ} .2$ & 1001.0 \\
\hline 83 & $28 / \mathrm{VII}$ & '83 & $71^{\circ} \quad 7^{\prime}$ & $62^{3} 39^{\prime}$ & 69 & $\gg$ & $+1^{\circ} .5$ & 1001.0 \\
\hline
\end{tabular}




\begin{tabular}{|c|c|c|c|c|c|}
\hline \multicolumn{2}{|c|}{ Water a/d bodem. } & \multirow{2}{*}{$\begin{array}{l}D \text { a u } \\
\quad \text { in } \\
\text { u r e } n .\end{array}$} & \multirow{2}{*}{ 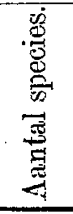 } & \multirow{2}{*}{ Dreggereedsehap. } & \multirow{2}{*}{ A anmerkingen. } \\
\hline Temp. & Dens. & & & & \\
\hline$-0^{\prime} .8$ & 1025.0 & $45 \frac{1}{2}$ uur & 26 & vijf zwabbers. & \\
\hline$-1 \cdot 4$ & 1025.0 & $73 \cdot \operatorname{unr}$ & 24 & $\gg$ & talrijke wormkokers. \\
\hline-1.5 & 1024.5 & 30 uur & 21 & $\gg$ & \\
\hline$-1^{\circ} .4$ & 1024.5 & $42 \mathrm{uur}$ & 20 & groote dreg. & zeer groot aantal kogelronde moerasertsvormingen. \\
\hline$-0^{\prime} .3$ & 1025.0 & 24 nur & 37 & vijf zwabbers. & r \\
\hline-0.4 & 1025.5 & $28 \frac{1}{2}$ nur & 23 & $\gg$ & \\
\hline-0.8 & 1025.0 & 48 unur & 20 & $\gg$ & \\
\hline$-0^{\circ} .1$ & 1025.5 & $45 \frac{1}{2}$ uur & 42 & $\gg$ & \\
\hline-1.6 & 1024.0 & 50 uur & 19 & $\gg$ & 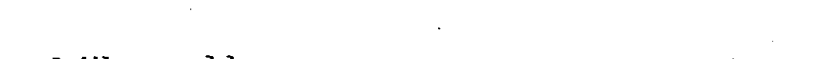 \\
\hline$-1 \cdot 5$ & 1026.0 & 50 uur & 9 & groote dreg en 1 zwabber. & talrijke stukken moeraserts. \\
\hline$-1^{\circ} .4$ & 1025.5 & $45 \mathrm{uur}$ & 32 & vijf zwabbers. & 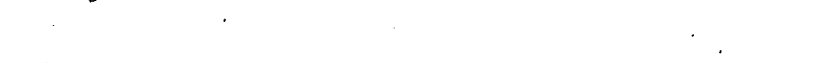 \\
\hline$-0^{\prime} .6$ & - & 21 uur & 36 & $\gg$ & \\
\hline-1.0 & 1025.0 & $24 \mathrm{uur}$ & 46 & $\gg$ & c \\
\hline-1.0 & 1025.5 & 48 nur & 25 & $\gg$ & \\
\hline-0.9 & 1025.0 & 27 uur & 26 & $\gg$ & eenige ronde moerasertsvormingen. \\
\hline- & - & 51 uur & 31 & $\gg$ & algen. \\
\hline$-1^{\circ} .1$ & 1025.0 & $27 \mathrm{uur}$ & 31 & $\gg$ & \\
\hline-0.8 & 1026.0 & 72 nur & 14 & $\gg$ & \\
\hline$-0^{\circ} .6$ & 1025.0 & 24 uur & 40 & $\gg$ & \\
\hline-0.8 & 1024.0 & $51 \cdot u n r$ & 32 & $\gg$ & \\
\hline-0.6 & 1025.0 & 25 uxr & 35 & $\gg$ & \\
\hline-0.9 & 1025.0 & 50 uur & 26 & $\gg$ & \\
\hline$-0^{\prime} .6$ & 1025.0 & $48 \quad$ unr & 35 & $\gg$ & \\
\hline-0.8 & 1025.0 & 47 unr & 33 & $\gg$ & \\
\hline-0.6 & 1025.0 & $30 \quad$ uur & 29 & $\gg$ & \\
\hline$-0^{\circ} .7$ & 1025.0 & 44 uur & 38 & $\gg$ & \\
\hline-0.6 & 1026.0 & 45 nur & 40 & $\gg$ & algen. \\
\hline-0.8 & 1025.0 & 48 nur & 32 & $\gg$ & . \\
\hline-0.7 & 1025.0 & 24 unr & 45 & groote dreg. & \\
\hline$-0^{2} .7$ & 1024.0 & 24. uur & 43 & $\gg$ & eenige steenen, moerasertsvormingen. \\
\hline-0.8 & 1025.0 & 72 uur & 9 & $\gg$ & de dreg kwam nagenoeg ledig op. \\
\hline$-1^{\circ}: 0$ & - & $48 \quad$ um & 29 & $\gg$ & 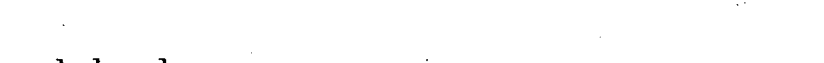 \\
\hline$-1^{\prime \prime} .2$ & 1025.0 & $48 \mathrm{umr}$ & 38 & vijf zwabbers. & enkele algen. \\
\hline$-1^{\circ} .2$ & 1025.0 & 28 um & 28 & $\gg$ & talrijke wormkokers. \\
\hline$-10^{\circ} .2$ & - & 28 uur & 22 & $\gg$ & zeer veel wormkokers. \\
\hline-0.6 & 1024.5 & 96 uur & 3 & groote dreg. & dreg onklaar. \\
\hline-1.0 & 1027.0 & 48 unr & 24 & $\gg$ & \\
\hline$-0^{\circ} .9$ & 1025.0 & 96 uur & 14 & $\gg$ & \\
\hline-0.9 & 1027.0 & 48 unr & 23 & $\gg$ & steenen. \\
\hline$-0^{\circ} .9$ & 1027.0 & 48 uur & 26 & $\gg$ & $\gg$ \\
\hline-0.8 & 1027.0 & 48 nur & 28 & $\gg$ & enkele steenen; eenige algen. \\
\hline-0.7 & 1024.0 & 72 uur & 24 & $\gg$ & enkele steenen. \\
\hline$-1^{\circ} .2$ & 1026.0 & 48 uur & 24 & $\gg$ & \\
\hline
\end{tabular}




\section{De diepte en de samenstelling van den bodem.}

De diepten, waarop de verschillende dreggingen plaatsvonden, liepen in zóóverre uiteen, dat de grootste diepte 108 en de kleinste 18 vaâm bedroeg, terwijl de meerderheid der loodingen tusschen 40 en 70 vademen aangaf.

Keeren wij nog eens tot den boven (p. 7) omschreven driehoek terug, dan zien wij daarbinnen de diepte afwisselen tusschen 94 en 44 vademen, echter met dien verstande, dat slechts éénmaal een diepte grooter dan 90 , en slechts driemal een kleiner dan 50 vaâm werd waargenomen. Daarentegen zijn van de loodingen, die gelijktijdig met het ophalen der dreg werden gedaan, er 26 die een diepté aanwijzen tusschen 50 en 60 vaâm,

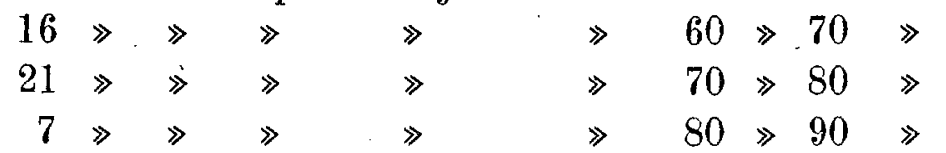

Birmen den driehoek is de diepte het aanzienlijkst in den tophoek en neemt aanvankelijk naar de basis toe allengs af van 88 tot 44 vaâm, om van het midden van de hoogte af, naar de beide andere hoekpunten toe, weêr te stijgen tot 78 resp.,65 vaâm. Zoo is het echter slechts in hoofdzaak, er komen vele onregelmatigheden voor, en veelal had ik gelegenheid waar te nemen, dat het terrein vrij golvend was.

Het is misschien niet onbelangrijk met een enkel woord hieraan vast te knoopen, hetgeen wij over 't geheel van de diepte der Karazee weten. De Zweedsche onderzoekers, aan wie wij, hetgeen tot nu toe van die zee bekend was, voornamelijk te danken hebben, nemen aan, dat zij zich oostelijk uitstrekt tot aan Kaap Tscheljuskin. Hiervan komt volgens mededeelingen door de leden der Vega-expeditie gedaan, de geheele Karische golf, benevens het gedeelte tot ver buiten de mondingen van $\mathrm{Ob}$ en Jenissei, en vandaar tot aan Kaap Tscheljuskin, geheel overeen met het meer oostwaarts gelegen gedeelte der Siberische ijszee. Bedoeld terrein kennmerkt zich namelijk door een zeer geringe diepte; 5, 10, 20 vaâm is zeer gewoon, 40 vaâm daarentegen reeds zeldzaam. Veel dieper integendeel is het westelijkst gedeelte der Karazee. Op de oostkust van NovaZembla loopt de lijn van 50 vaâm diepte op slechts eenige mijlen afstands van het land, van Kaap Mauritius tot aan de Karische poort toe; de diepte neemt hier snel toe en evenwijdig aan de geheele oostkust strekt zich een geul van 100-300 vaâm uit, die zich kenmerkt door water van lage temperatuur en groot zoutgehalte, alsook door een zeer rijk dierlijk leven. Verder oostwaarts stijgt de zeebodem meer en meer en vormt daar een 30-90 vaâm nnder den zeespiegel gelegen vlakte, die echter naar de kust van Jalmal toe nog aanzienlijk stijgt. Zooals uit het vorige hoofdstuk blijkt, valt het terrein van mijn onderzoek nagenoeg geheel op de bedoelde vlakte van 30 - 90 vaâm.

In verband met het boven gezegde kan het niet verwonderen, dat ook de afwisseling in de samenstelling van den bodem binnen de beperkte ruimte, waarvan hier sprake is, zeer gering was. De grond bestond gewoonlijk uit donker- of lichtgrijs, soms blauwachtig leem, waarin niet zelden zóó compakte klompen voorkwamen, dat zij aan stopverf deden denken. Dit leem was in den regel bedekt met een vrij dunne laag bruin, sterk ijzerhoudend slib of modder, dat op zeer opvallende wijze van het leem verschilde, welk laatste somtijds echter ook, ofschoon in zeer veel geringere hoveelheid, ijzeroxyd bevatte, dat als roodbruine strepen en banden in de grijze massa zichtbaar was. De grijze massa zelve kenmerkte zich door een groote armoede, ja niet zelden bijna volkomen gebrek aan dieren; zeer dikwijls werd er echter een ongelooflijke massa half vergane wormkokers in aangetroffen, veelal ook eveneens halfvergane schalen van Lamellibranchiaten, maar deze nooit in bizonder groote họeveelheid. Deze laatsten vertoonden gewoonlijk de in 't oogvallende bizonderheid, dat zij midden in een kleine cirkelronde opening met een middellijn van ongeveer $1 \mathrm{mM}$. bezaten. Het waren voor het meerendeel schelpen van Tellina lata, Leda pernula en eenige Astarte-species. 
De kokers waren voor zoover ik ze bestemmen kon, voornamelijk afkomstig van de volgende dieren : Pectinaria hy perborea, 4 à 5 cM. lang, kegelvormig, hard en gevormd uit zand en andere bodembestanddeelen; Onuphis conchilega, plat en samengesteld uit stukjes van Molluskenschalen en kleine steentjes; de lange, dunne doorschijnend perkamentachtige buizen waren afkomstig van Spiochaetopterus typicus; evenzoo waren de lange leerachtige kokers van $\mathrm{P}$ ot a milla en andere S e r puliden niet zelden, terwijl eindelijk nog verschillende andere tubicole A n nelide n hier door de overblijfselen hunner min of meer in staat ván onthinding verkeerende woningen vertegenwoordigd waren. De meeste dezer wormkokers kwamen met hun levende bewoners, maar dan meestal in veel geringer aantal, ook voor in de bruine het leem bedekkende sliblaag, die dan ook gewoonlijk, in tegenstelling van het leem, een vrij rijk, soms zelfs zeer rijk dierlijk leven vertoonde. Als een eigenaardige bizonderheid wil ik hier nog doen opmerken, dat de tuben van Pectinaria hyperborea in zeer vele gevallen in plaats van het er in tehuis behoorende dier een $\mathrm{Phascolos}$ oma sp. bevatten. Dit bleek op niet minder dan 28 stations het geval te zijn, en niet zelden werd dit dier op deze wijze in zeer talrijke exemplaren angetroffen.

De ligging der twee verschillende bestanddeelen van den bodem maakt het nu ook duidelijk, waarom de zwabbers hier veelal met zooveel gunstiger resultaat konden worden aangewend dan de dreg. De eersten toch sleepten slechts door de oppervlakkige laag en namen daaruit de dieren tot zich; de zware dreg daarentegen zonk bij de dikwijls uiterst langzame beweging van het ijs ten opzichte van den bodem, meer of minder diep in, en bracht meestal niets dan een groote hoeveelheid van het grijsblauw leem mede naar boven.

Dat de bruine bovenlaag meestal vrij dun was, bewees het volgende feit: telkens, wanneer de zwabbers waren opgehaald, werd terstond het Ekman-apparaat neergelaten, om daarmede water van den bodem op te halen; om dezen toestel sneller te laten zakken, werd een ijzeren gewicht van 5 of 10 kilo er aan bevestigd, en altijd nam' ik waar dat, terwijl de zwabbers geheel of vooral aan hun bovengedeelte, dat het minst geflotteerd had, uitsluitend met het bruine slib bedekt waren, de platte ondervlakte van het ijzeren gewicht steeds grijs leem mede naar boven bracht, en dus door de geheele bovenlaag was heengezakt.

In de bovenlaag kwamen ook herhaaldelijk zoogenaamde moerasertsvormingen voor, waarmede allerlei voorwerpen, als steentjes, schelpen enz. waren omgeven. Ik vond ze voornamelijk in twee vormen: de eerste deed zich voor als platte, min of meer cirkelronde, soms ook ovale voorwerpen, met een middellijn van 10 tot $15 \mathrm{cM}$; deze zelfde voorwerpen werden ook door NoRDENSKJöLD gevonden en volgens hem komen ze bij Dicksonhaven in zulk een menigte voor, dat zij met voordeel tot de ijzerfabricatie zouden kunnen gebruikt worden, indien de streek slechts wat minder ontoegankelijk was. De andere soort van moerasertsvormingen, die ik aantrof, deed zich voor als over 't algemeen vrij zuiver ronde kogels, ongeveer van de grootte van gewone knikkers of iets daarboven. Deze kwamen soms in waarlijk verbazende hoeveelheid voor. Op station 44, waar ik de dreg gebruikte, bedroeg het gezamelijk gewicht der kogels, die hiermede naar boven kwamen, 47 $\frac{1}{2}$ kilo, terwijl zij met het vrij dunne slib, waarmede ze vermengd waren, te zamen genomen een volumen van $72 \mathrm{dM}^{3}$. innamen. Ik berekende hun aantal op ongeveer 14750, waarvan $90 \%$ vrijwel bolvormig, de overigen min of meer, soms vrij onregelmatig waren. Ik ben overtuigd, dat zoowel de platte als de bolvormige voorwerpen veel algemeener over het terrein, dat ik onderzocht heb, verspreid waren dan men oppervlakkig zou denken; uit den aurd der zaak toch waren de zwabbers, die 42 maal uitsluitend gebruikt werden, ten eenemale ongeschikt om ze vast te houden 'en naar boven te brengen, daar slechts kleine bolletjes een enkele maal tusschen de draden bleven hangen; daaraan is het dan ook toe te schrijven, dat ik het voorkomen van de eerste soort slechts drie, dat der laatste slecht zes maal heb aangeteekend.

Alleen bij de dreggingen 21-24 vond ik eenig zand met het leem gemengd. STuxberg vond in 1878, oostelijk en zuidoostelijk van het terrein, dat door mij onderzocht werd, herhaaldelijk 
met zand gemengd leem en met leem gemengd zand, of zelfs zuiveren zandbodem, terwijl noord. waarts de zuivere leembodem zich schijnt voort te zetten tot ongeveer $72 \frac{1}{2}^{\circ} \mathrm{N}$. B., en op deze breedte, alsook op $72^{\circ}$ N. B., ook tot vrij dicht onder de Jalmalkust geen zand wordt aangetroffen.

Gewone steenen van $\mathrm{Si} \mathrm{O}_{2}$ kwamen, zonder juist veelvuldig te zijn, af en toe doch steeds in gering aantal, voor.

\section{Het water op den bodem en aan de oppervlakte.}

Zooveel mogelijk werden bij iedere dregging serial-waarnemingen, of althans temperatur-en densiteitsbepalingen van het zeewater op den bodem en aan de oppervlakte gedaan. Het werktuig, waarmede dit geschiedde, was het Ekman-apparaat, dat, hoe aanbevelenswaard ook, vooral voor de betrekkelijk geringe diepten, waarmede wij steeds te doen hadden, bij de strenge winterkoude voor serial-waarnemingen onbruikbaar was. Het geval wilde namelijk dat, wanneer de toestel eenmaal te water was geweest, hij voor de tweede maal den dienst weigerde, om de eenvoudige reden, dat hij vastvroor en daardoor bij het aanhouden niet meer dicht viel. Er bleef dus niets anders over dan, om hem telkens, na eenmaal te water te zijn geweest, in huis bij de kachel te laten ontdooien en volkomen te drogen. Dat onder zulke omstandigheden aan serialwaarnemingen niet te denken viel, is duidelijk, en meestal moest men zich dus met het water van den bodem tevreden stellen, dat dan toch voor mij van het meeste belang was.

Dé temperatur van het water op den bodem liep niet zeer uiteen en wisselde af van $+0^{0} .3$. tot $-1^{\circ}, 8$, was echter in slechts twee gevallen + en bedroeg gemiddeld $-0^{\circ} .8$. De densiteit van het bodemwater varieerde tusschen 1023 en 1027, zuiver water als 1000 aangenomen. $\mathrm{Bij}$ het oppervlaktewater daarentegen was een nog veel grooter verschil waar te nemen, namelijk. tusschen den winter en den zomer. Van Januari tot het laatst van de maand Mei was de iemperatuur. schommelende tusschen $-2^{\circ} .0$ en $0^{\circ} .0$, evenwel slechts bij uitzondering lager dan $-1^{0} .7$ en hooger dan $-1^{\circ} .4$, terwijl de densiteit gewoonlijk afwisselde tusschen 1019 en 1022.5, en eenmaal tot 1024 steeg. 'Toen evenwel in de laatste dagen van Mei en het begin. van Juni de temperatuur der lucht voor het eerst langeren tijd eenige graden boven het vriespunt steeg, en dientengevolge het smeltingsproces van de sneeuwlaag en het ijs zelven begon, steeg niet alleen de temperatuur van het water in de open gaten tusschen het jjs, maar dit water werd ook weldra volkomen drinkbaar, een licht te verklaren verschijnsel, wanneer men bedenkt, dat het smeltings-. water overal in kleine beekjes naar deze gaten liep en zich daar in zee stortte. De overgang was vrij plotseling, gelijk nit de volgende getallen blijkt:

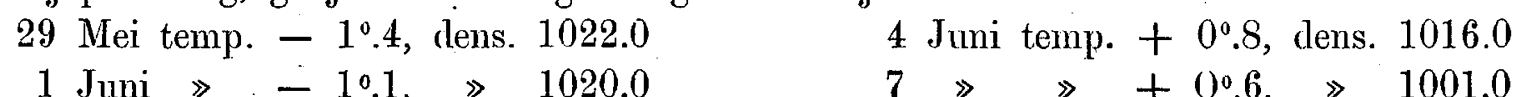

Sedert bleef de temperatuur tusschen $+0^{\circ} .9$ en $+0^{\circ} .4$, terwijl de densiteit constant op 1001 bleef. Zelfs in de maand Augustus, gedurende onze terugtocht, had ik gelegenheid waar. te nemen, dat het water zelfs daar, waar het breede kanalen vormde, aan de oppervlakte drinkbaar was; eerst later, toen het pak losser en losser werd en wij de grenzen er van naderden, werd ook het zeewater meer en meer brak. 


\section{De op de verschillende stations verzamelde dieren.}

Geeft de in Hoofdstuk III opgenomen tabel een overzicht van alle gegevens, die bij een dregging van belang kunnen zijn, in het hierachter volgende vindt men een lijst van de dieren, die op elk station werden verzameld.

Deze lijst maakt geen aanspraak op volledigheid ;' van vele vormen was ik voorloopig niet in staat de soort of somtijds zelfs het geslacht vast te stellen, daar mij de daartoe vereischte literatuur ten eenemale ontbrak. In de eerste plaats geldt dit voor de Hydrozoën en de Bryozoën, wier bestemming voornamelijk tot later onderzoek is uitgesteld. Het behoeft dus verder geen betoog, dat, bij dit nader onderzoek van het door mij medegebrachte materiaal, de lijst eene belangrijke nitbreiding zal moeten ondergaan.

Station 1. Zeer rijke dregging.

Saxicava pholadis; 'Lellina lata; 2 soorten van Astarte; Cardium sp.; Leda pernula; eieren van Mollusken; eenige Gastropoden.

Pycnogonide (Nymphon sp.);

Pagurus sp., waaronder $q$ exemplaren met eieren; Sabinea septemcarinata (q met eieren); Acanthostephia Malmgreni; Anonyx lagena en nog eenige Amphipoden; Balanus sp. op steenen en op schalen van Mollusken.

Nereis zonata; Potamilla sp.; Pectinaria hyperborea, nog eenige tubicole Anueliden en voorts een overgroote massa ledige kokers van Spiochaetopterus typicus.

Hornera lichenoides, Flustra membranaceo-truncata; 2 species van Alcyonidiurn; en nog een Bryozoe.

Asterophyton eucnemis; Ophioscolex glacialis; Ophiopholis aculeata; Ophiacantha bidentata ; Ophioglypha (robusta?) ; Ctenodiscus crispatus; - Heliaster sp.

Eenige Hydroiden en Spongien.

Station 2.

Een Blenniide; een Trigla of verwant geslacht; een Cataphract.

Buccinum sp.; Dendronotus arborescens; nog eenige Gastropoden en de ledige schalen er van; Panopaea (norvegica?); Astarte sp.; Cyprina islandica, Cardium sp.; nog eenige Lamellibranchiaten.

Hyas aranea; Pagurus sp.; Crangon boreas; Hippolyte sp., waaronder $q$ met eieren; Acanthostephia Malmgreni; Anonyx lagena; nog een Amphipode; Balanus sp. talrijk op steenen en :schelpen.

Nereis zonata; eenige wormkokers; enkele Bryozoën.

Ophioglypha nodosa;

Enkele Hydroiden en Spongien;

Station 8. Arme dregging.

Panopaea? sp.; eenige andere kleine Lamellibranchiaten; - Hippolyte sp. - Nereis zonata ; enkele Bryozoen, waaronder een Alcyonidium soort;

Trochostoma boreale in verscheidene exemplaren;

Een Hydroide en een paar Bekersponsen;

Station 4.

De dreg kwam geheel verscheurd op, waarschijnlijk veroorzaakt door steenen op den bodem, en door te snelle drift.

Station 5.

Eenige Lamellibranchiaten en Gastropoden;

Nymphon hirtus; Crangon boreas; Hyppolyte sp.; 
Nereis sp.; groote hoeveelheid kokers van Serpuliden, enz.

Alcyonidium mammillatum; Flustra membranaceo-truncata;

Trochostoma boreale; Ophiacantha bidentata; Ctenodiscus crispatus ;

Eenige spongiën;

Station 6. Zeer arme dregging.

Eenige Amphipoden (waaronder kleine exemplaren van Acanthostephia Malmgreni); - Enkele Anneliden;

Trochostoma boreale;

Station 7. Dreg ging door ijspersing verloren.

Station 8. Dreg onklaar; in den Zwabber:

Caprella echinata;

Ophiacanta bidentata; Ctenodiscus crispatus; Archaster tenuispinus;

Station 9.

Panopaea? sp. (talrijk); Astarte sp.; Leda pernula;

Nymphon hirtus;

Eenige Anneliden; kokers van Serpuliden: een Nemertine;

Alcyonidium en eenige andere Bryozoën;

Trochostoma boreale; Ophioglypha Sarsi; Archaster tenuispinus,

Eenige Hydroiden, waaronder Sertularia's;

Station 10.

Een Cataphract;

Tellina lata; Astarte sp.; — Leda pernula; eenige andere Lamellibranchiaten; - Nymphor hirtus; Hyppolyte sp.; Munnopsis typica ; Idotea entomon en Sabinei ; Acanthostephia Malmgreni;. Anonyx lagena; - Glycera sp.; Pectinaria hyperborea; Ammotrypane aulogaster; talrijke kokers;.

- Eenige Bryozoën, waaronder Alcyonidium sp.; - Trochostoma boreale, in zeer talrijke exemplaren; Asterophyton Linckii; Ophiacantha bidentata; Ctenodiscus crispatus; Pedicellaster typica, nog 1 Asteride;

Eenige Hydroiden en Beckersponsen.

Station 11. Arm dierleven.

Saxicava pholadis; Panopaea sp.; talrijke ledige en gebroken schalen van Tellina lata, Astarte sp. en Leda pernula;

Een Amphipode (Anonyx? sp.);

Glycera sp.; Pectinaria hyperborea; groote hoeveelheid Serpuliden- en andere kokers, allen half vergaan; - Alcyonidium sp.; Flustra membranaceo-truncata; - Ctenodiscus crispatus ;

\section{Station 12}

Tellina lata; Astarte sp.; talrijke gebroken schalen van deze en andere Mollusken;

Péctinaria hyperborea (kokers); Ammotrypane aulogaster; talrijke kokers van Anneliden; Alcyonidium sp.;

'Trochostoma boreale Ctenodiscus crispatus.

Enkele Beckersponsen.

Station 13.

Vele schalen van Mollusken; - Idotea entomon; - Eenige Ammeliden ; - talrijke wormkokers; - Alcyonidium sp.

Asterophyton sp.; Ophiacantha bidentata;

Station 14. Tellina lata; Astarte sp.; schalen van andere Lamellibranchiaten;

Idotea Sabinei; Anonyx sp.;

Kokers van Pectinaria hyperborea en andere wormen.

Alcyonidium sp.; Flustra membranaceo-truncata ; - Trochostoma boreale ; Ophiacantha bidentata ;

Ophioglypha Sarsi; Ctenodiscus crispatus; 


\section{Station 15.}

Tellina lata; Astarte sp.; nog 1 Lamellibranchiaat;

Nymphon hirtus; Idotea Sabinei;

Kokers van Pectinaria hyperborea e. a. wormen;

Eenige Bryozoen, waaronder Alcyonidium sp. en Flustra;

Trochostoma boreale (talrijk); Astcrophyton (eucnemis ?); Ophiacantha bidentata; Ophioglypha Sarsi; - Ctenodiscus crispatus; - Hydroiden en eenige Bekersponsen.

Station 16.

Buccinum sp.; Tellina lata; fragmenten van schalen van Astarte sp. en Leda pernula;

Idotea entomon;

Pectinaria hyperborea (kokers); Ammotrypane aulogaster; - eenige Bryozoën; - Trochostoma boreale (zeer talrijk); Ophiacantha bidentata (zeer talrijk); Ophioglypha Sarsi ; Ctenodiscus crispatus;

Eenige koloniën van Hydroiden.

Station 17. Zeer rijke dregging.

Een Blenniide en een Cataphract;

Panopaea sp.; Astarte sp.; schalen van Tellina lata e. a. Lamellibranchiaten

Nymphon sp.; Sabinea septemcarinata; Hippolyte sp.;. Munnopsis typica; Idotea Sabinei; Acanthostephia Malmgreni; Anonyx lagena; - Glycera sp.; Nereis sp.; kokers van Pectinaria hyperborea e. a.; Phascolosoma sp.; - Trochostoma boreale; Ophiacantha bidentata: Ophioglypha nodosa en Sarsi; Ctenodiscus crispatus; nog een Asteride; eenige Actinien;

Station 18.

Munnopsis typica; - Pectinaria hyperborea; een Bryozoe; - Ophiacantha bidentata; Ophio. glypha Sarsi; Antedon Eschrischtii (zeer jeugdig exemplaar);

Station 19.

Tellina lata; Astarte sp.; Leda pernula; ledige schalen van andere Lamellibranchiaten; - 1 Amphipode; - Nereis virens; Eunice sp.; Pectinaria hyperborea; een Chaetopode en nog twee kleine Anneliden; talrijke wormkokers; - Alcyonidium sp.; Flustra membranaceo-truncata en talrijke andere Bryozoën;

Trochostoma boreale; Ctenodiscus crispatus;

Station 20.

Een. Gastropode; verder voornamelijk schalen van Leda pernula, Tellina lata en Astarte sp.;

Idotea Sabinei; Anonyx pumilus en nog een Amphipode; Scalpellum sp. op Flustra;

Potamilla sp.; talrijke kokers van Serpuliden; Pectinaria hyperborea; Eunice sp.; Phascolosoma sp.; een Nemertine; - Flustra sp.; Alcyonidium sp. (talrijk); -- Trochostoma boreale; Ophiacantha bidentata; Ophioglypha Sarsi; Ctenodiscus crispatus;

Station 21.

Saxicava pholadis; Tellina lata; Astarte sp.; Leda pernula; eieren van Mollusken; - Anonyx lagena; nog 1 Amphipode; Calanus of verwant geslacht; Scalpellum sp. sp.; - Nereis zonata; Eunice sp.; Potamilla sp.; buitengewoon talrijke kokers van Serpuliden en andere wormen; Pectinaria hyperborea (zeer talrijk); nog 1 Annelide; Phascolosoma sp.; - Alcyonidium sp.; Flustra sp.;

Trochostoma boreale; Ophioglypha Sarsi; Ctenodiscus crispatus; Archaster tenuispinus ;

Eenige soorten Hydroiden;

\section{Station 22.}

Saxicava pholadis; Tellina lata; Astarte sp.; Loda pernula (schalen); Pecten grönlandicus (bizonder talrijk);

Munnopsis typica (alleen defecte exemplaren); Anonyx sp., ook $\&$ met eieren; nog een Amphipode; - Nereis sp.; Eunice sp.; Polynoë sp.; Pectinaria hyperborea (zeer talrijk); Ophelia sp.; 
nog een tubicole Annelide; Phascolosoma sp.; - Eschara sp.; Alcyonidium mammillatum;. 'Trochostoma boreale; Ophiacantha bidentata; Ophioglypha Sarsi; Ctenodiscus crispatus; -

Beker- en andere sponsen; eenige Hydroiden;

Station 29.

Schalen van 'Tellina lata en Astarte sp.; verder Leda pernula en zeer talijke exemplaren van Pecten grönlandicus; - Nymphon hirtus; Mysis sp.; Munnopsis typica; Idotea biscuspida; Anonyx Wahlii en nog een Anonyx sp.; Atylus carinatus; nog een Amphipode; Calanus sp.; - Nereis zonata; Pectinaria hyperborea (zeer talrijk); kokers van Anneliden; Phascolosoma sp.; eenige Bryozoën;

Trochostoma boreale; Asterophyton Linckii; Ophiacantha bidentata (talrijk); Ophioglypha Sarsi ; Ctenodiscus crispatus; - Hydroidpolyp en een Spongia.

Station 24.

Eieren van Buccinum?; Leda pernula; Pecten grönlandicus; nog een Lamellibranchiaat; Nymphon hirtus; Idotea bicuspida; Scalpellum sp.; - Nereis zonata en eenige andere Anneliden; kokers van Pectinaria hyperborea; Phacolosoma' sp.; 1 Nemertine; - verscheidene Bryozoën als: Flustra sp., Eschara sp., Hornera lichenoides e. a.; - Asterophyton eucnemis en Linckii; Ophioscolex glacialis; Ophiacantha bidentata (zeer talrijk); Ophioglypha Sarsi ; Ctenodiscus crispatus; Archaster tenuispinus; Cribrella sanguinolenta; - Beker- en verschillende andere sponsen.

Station 25.

Nymphon hirtus; Diastylis spinulosa; Idoted bicuspida en Sabinei ; Anonyx lagena ; Caprella echinata; Een Chaetopode en een Nemertine; - talrijke Bryozoën als: Hornera, Retepora, Discopora, Eschara, Flustra en meer. - Ophioscolex glacialis; Ophiacantha bidentata; Ophioglypha Sarsi; Ctenodiscus crispatus; Archaster tenuispinus; Cibrella sanguinolenta; Antedon Eschrichtii (zeer jong exemplaar); - Actinia sp.;

Station 26.

T'ellina lata (schalen); 1 Lamellibranchiaat;

Nymphon hirtus (talrijk, ook een $ठ$ met eieren); Idotea bicuspida; Calanus? sp.; — Onuphis conchilega, Polynoë sp.; Potamilla sp.; Brada villosa; nog eenige Anneliden; Phascolosoma; Nemertine; - Hornera lichenoides; Eschara sp.; Retepora sp.; Flustra sp., e. a. Bryozoën; Trochostoma boreale; Ophioscolex glacialis; Ophiacantha bidentata (in zeer groot aantal); Ophioglypha Sarsi en nodosa; Hymenaster sp.; Ctenodiscus crispatus; Archaster tenuispinus (zeer talrijk); Cribrella sanguinolenta; Antedon Eschrichtti;

Station 27.

Saxicava pholadis (schalen); 'Tellina lata (voornamelijk schalen); - Nymphon hirtus; Hyppolyte sp.; Mysis sp.; Munnopsis typica (allen defect); Scalpellum sp. (op Flustra);

Nereis zonata; nog 1 Annelide; Phascolosoma sp.;

Alcyonidium sp.; Flustra sp.; Eschara sp. e. a. Bryozoen.

Trochostoma boreale; Ophioscolex glacialis; Ophiacantha bidentata; Ophioglypha Sarsi ; Ctenodiscus crispatus; Archaster tenuispinus;

1 Spongia en 2 sp. Hydroidpolypen.

Station 28.

Gastropode en schaalfragmenten van een andere; Pecten grönlandicus; eieren van een Mollusk; Nymphon hirtus; Munnopsis typica; Idotea bicuspida; Anonyx lagena; - Onuphis conchilega; Nereis zonata (talrijk); nog een Nereissoort; 1 Nemertine; - Discopora sp.; Eschara sp.; Hornera lichenoides; andere Bryozoen; - Ophiacantha bidentata (zeer talrijk); - Ophioglypha Sarsi ;

Ctenodiscus crispatus; Archaster tenuispinus; Cribrella sanguinolenta ;

Station 29.

Nymphon hirtus (talrijk); - Anonyx lagena; 
Vele kokers van Anneliden; - Hornera lichenoides; Eschara sp.; en eenige andere Bryozoen; - Ophiacantha bidentata (talrijk); Ophioglypha Sarsi; Ctenodiscus crispatus (talrijke jonge exemplaren); Archaster tenuispinus; - Spongien;

Station 30. Arme dregging.

Pecten grönlandicus; Idotea Sabinei; Scalpellum sp.;

Kokers van Serpuliden enz.; - Flustra membranaceo-truncata; - Trochostoma boreale ; Ophioglypha Sarsi;

Station 31.

Molgula grönlandica; - Nymphon hirtus;

Nereis zonata; Polynoë sp.; kleine Annelide; talrijke wormkokers;

Van Bryozoen: Flustra sp.; Eschara sp.; Hornera lichenoides e. a.

Ophioscolex glacialis; Ophiacantha bidentata; Ophioglypha nodosa en Sarsi ; Ctenodiscus crispatus ;

Archaster tenuispinus; Cribrella sanguinolenta; - eenige Spongien;

Station 32.

Nymphon hirtus; Munnopsis typica (fragmenten); Idotea entomon en Sabinei; een kleine Amphipode; Scalpellum sp.;

Een Annelide; - Alcyonidium, Eschara, Flustra en nog 1 Kalkbryozoe ; - Ophioscolex glacialis ; Ophiacantha bidentata; Ophioglypha Sarsi ; Ctenodiscus crispatus (zeer talrijk); Archaster tenuispinus (talrijk); Cribrella sanguinolenta; - een Spongia.

Station 38.

Leda pernula ; - Idotea entomon; - Glycera sp.; eenige Anneliden; talrijke wormkokers ; Alcyonidium sp.; Hornera lichenoides; Eschara sp.; Flustra membranaceo-truncata ; -

Trochostoma boreale; Ophiacantha bidentata (talrijk); Ophioglypha Sarsi ; Archaster tenuispinus ;

\section{Station 34.}

Molgula crystalina; - Pecten grönlandicus ;

Nymphon hirtus; nog 1 Pygnognide; Crangon boreas; Munnopsis typica; Idotea Sabinei ; Anonyx lagena; Scapellum sp.;

Polynoë sp.; kokers van Serpuliden enz.; Eschara sp.; Hornera-sp.; Trochostoma boreale; Ophioscolex glacialis; Ophiacantha bidentata (talrijk); Ophioglypha nodosa en Sarsi; Ctenodiscus. crispatus (zeer talrijk); Archaster tenuispinus; Solaster tumidus; Cibrella sanguinolenta; - een Spongia in talrijke exemplaren;

Station 85.

Pecten grönlandicus; - Nymphon hirtus; Munnopsis typica; Idotea Sabinei; - een kleine Annelide; - Hornera lichenoides; Flustra membranaceo-truncata; Eschara sp. en nog eenige andere Bryozoen; - Ophioscolex glacialis; Ophiacantha bidentata (zeer talrijk); Ophioglypha nodosa ; Ctenodiscus crispatus (talrijk); Archaster tenuispinus; Antedon Eschrichtii; - 1 Spongia;

Station $\mathbf{3 6}$.

Molgula sp.; - Pecten grónlandicus; - Nymphon hirtus; Diastylis spinulosa; Idotea Sabinei ;

Polynoë sp.; Pectinaria hyperborea; nog 1 Annelide; Phascolosoma sp.; - Hornera lichenoides. (zeer talrijk); Flustra sp.; Retepora en nog eenige Kalkbryozoen;

Ophioscolex glacialis; Ophiacantha bidentata; Ophioglypha nodosa; Ctenodiscus crispatus; Archaster tenuispinus; Solaster furcifer;

Station 37.

Leda pernula; Pecten grönlandicus; Scalpellum sp ; - Glycera sp.; Polynoë sp.; Pectinaria hyperborea (kokers); Ammotrypane aulogaster; 1 Chaetopode; Phascolosoma sp.; 1 Nemertine ; Hornera lichenoides; Retepora sp.; Flustra membranaceo-truncata; Eschara sp. en een aantal andere Kalkbryozoen; 
Ophioscolex glacialis; Ophiacantha bidentata (talrijk); Ophioglypha Sarsi; Ctenodiscus crispatus ; Archaster tenuispinus; nog een kleine Asteride; Antedon Eschrichtii ; - 3 soorten van Spongien; Station 38. Rijke dregging; Echinodermen zeer overheerschend.

Molgula crystalina; - Yoldia sp.; Pecten grönlandicus; -- Nymphon hirtus; Idotea Sabinei; Scalpellum sp.

Nereis zonata; Polynoë sp.; een Chaetopode; kokers von Anneliden; Phascolosoma sp.; een Nemertine; - Alcyonidium gelatinosum en mammillatum; Hornera sp.; Flustra sp.; Eschara sp.; Retepora sp. en nog twee Kalkbryozoen; - Asterophyton Linckii; Ophioscolex glacialis (talrijk); Ophiacantha bidentata (zeer talrijk); Ophioglypha Sarsi; Ctenodiscus crispatus; Archaster tenuispinus; Solaster furcifer; Cribrella sanguinolenta; Antedon Echrichtii; - jonge Bckersponsen en een Hydroidenkolonie;

Station 39. Rijke dregging.

Pecten grönladicus; - Nymphon hirtus; Diastylis scorpioides; Idotea Sabinei; Caprella echinata; Scalpellum sp.; - Nereis virens; N. zonata; Onuphis conchilega; Polynoë sp.; Pectinaria hyperborea; nog twee twee Chaetopoden; een Oligochaet; Phascolosoma sp.; - Alcyonidium mammillatum; Eschara sp.; Flustra membranaceo-truncata; Hornera lichenoides; Retepora sp. en nog 5 andere Kalkbryozoen.

'Trochostoma boreale; Ophioscolex glacialis (talrijk); Ophiacantha bidentata; Ophioglypha Sarsi; Ctenodiscus crispatus (talrijk); Archaster tenuispinus; Cribrella sanguinolenta;

Spongia en Hydroidenkoloniën.

Station 40.

Leda pernula; Pecten grönlandicus; - Diastylis spinulosa; Munnopsis typica (defect); Idotea Scalpellum.sp.; - 2 soorten van Polynoë; Hornera lichenoides en violacea; Retepora sp.; Eschara sp.; Flustra membranaceo-truncata; nog een Kalkbryozoe; - Ophioscolex glacialis; Ophiacantha bidentata; Ophioglypha nodosa; Archaster tenuispinus; Cribrella sanguinolenta; - Hydroiden en 1 Spongia.

Station 41.

Pecten grönlandicus; - Nymphon hirtus ; Idotea Sabinei; Scalpellum sp.; - 2 soorten van Polynoë; Onuphis conchilega; Pectinaria kokers; een Chaetopode; nog cen Annelide; Phascolosoma sp.; Planaria sp.; - Hornera lichenoides en violacea; Eschara sp.; 2 soorten van Flustra; nog twee Kalkbryozoen.

Trochostoma boreale; Ophioscolex glacialis ; Ophiacantha bidentata ; Ophioglypha nodosa ; Ctenodiscus crispatus; Archaster tenuispinus; Antedon Eschrichtii ; - Hydrozoen.

Station 42.

Pecten grönlandicus; - Diastylis spinulosa; Idotea Sabinei ; - Nereis zonata; Polynoë sp.; Chaetopode ; een kleine Annelide; kokers van Serpuliden e. a.; Phascolosoma sp.; een Nemertine; Alcyonidium mammillatum; Hornera lichenoides en violacea sp,; Flustra membranacaceo-truncata; - Eschara sp.; - nog 3 Kalkbryozoen; - Trochostoma boreale; Asterophyton Linckii; Ophioscolex glacialis; Ophiacantha bidentata; Ctenodiscus crispatus; Cribrella sanguinolenta;

Station 43.

Molgula grönlandica; - Tellina lata (schalen); Pecten grönlandicus ; - Idotea Sabinei; Anonyx Wahlii; - Nereis zonata; nog een Nereis sp.; talrijke wormkokers en Nemertine ; - Alcyonidum sp.; Horinera lichenoides; Eschara sp.; nog een Kalkbryozoe;

Ophioscolex glacialis; Ophiacantha bidentata (talrijk); Ophioglypha Sarsi en nodosa; Ctenodis. cus crispatus; Archaster tenuispinus; Cribrella sanguinolenta; - Spongia;

Station 44.

Tellina lata; - Diastylis spinulosa; Munnopsis typica; Idotea Sabinei en entomon; Anonyx lagena;

Flycera sp.; Pectinaria hyperborea (kokers); talrijke andere kokers; Phascolosoma sp.; - 
Alcyonidium gelatinosum; nog 1 Bryozoe; - Trochostoma boreale; Ophioscolex glacialis ; Ophiacantha bidentata; Ophioglypha Sarsi; Ctenodiscus crispatus; Archaster tenuispinus; Cribrella sanguinolenta.

Stalion 45.

Pecten grönlandicus; nog twee andere Lamellibranchiaten; - Nymphon hirtus en nog een Pygnogonide; Diastylis scorpioides; D. (Goodsiri?); Munnopsis typica; Idotea Sabinei ; Caprella sp.; - Nereis virens en zonata; Polynoë sp.; 1 Chaetopode en kokers; Phascolosoma sp.; een Nemertine; - Hornera lichenoides; Flustra sp.; Eschara sp.; Crisia sp. en nog drie Kalkbryozoen.

Asterophyton Linckii; Ophioscolex glacialis; Ophiacantha bidentata (zeer talrijk); Ophioglypha Sarsi; Ctenodiscus crispatus (vooral jeugdige exemplaren); Archaster tenuispinus (zeer talrijk); Cribrella sanguinolenta (vooral jonge exemplaren); Solaster furcifer; Antedon Eschrichtii ; Spongia én Hydroidkoloniën;

Station 46.

Pecten grönlandicus; Nymphon hirtus; Diastylis spinulosa; Munnopsis typica; een Amphipode; - Nereis zonata; twee soorten van Polynoë; kokers; - Eschara sp.; Hornera lichenoides; Hlustra sp.; nog een Kalkbryozoe; - Ásterophyton Linckii; - Ophioscolex glacialis ; Ophiacantha bidentata (zeer talrijk); Ctenodiscus crispatus; Archaster tenuispinus (zeer talrijk); Solaster tumidus; Cribrella sanguinolenta; - Hydroidenkolonien en : Spongiën ;

Station 47.

Nymphon hirtus; nog een Pycnogonide; Idotea Sabinei en bicuspida; Anonyx Wahlii en lagena; nog een Amphipode;

Polynoë sp.; nog een Annelide; - Eschara sp.; Flustra membranaceo-truncata; twee andere Kalbryozoen;

Ophioscolex glacialis; Ophiacantha bidentata (zeer taalrijk); Ophioglypha Sarsi; Ctenodiscus crispatus; Archaster tenuispinus (zeer talrijk); Cribrella sanguinolenta; - Hydroidkolonie;

Station 48.

'Trigla? sp.; - Molgula grönlandica en crystalina; - 'Tellina lata.(schalen); Pecten grönlandicus; nog een Lamellibranchiaat; - Nymphon hirtus; nog twee soorten soorten van Pycnogoniden, waaronder een $\sigma^{*}$ met eieren; Mysissp.; Diastylis Rathkei; Munnopsis typica (allen defect); Idotea Sabinei; Anonyx lagena; een Calanide; Scalpellum sp.; - Nereis zonata; nog een Nereis sp.; Polynoë sp.; Spiochaetopterus typicus; kokers van dezelfde e. a. soorten; - Alcyonidium mammillatum; Hornera lichenoides en violacea ; Crisia sp.; Flustra sp.; Eschara sp.; Retepora sp.; nog 2 Kalkbryozoen; - Ophioscolex glacialis; Ophiacantha bidentata (talrijk); Ophioglypha Sarsi en nodosa; Ctenodiscus crispatus; Archaster tenuispinus; Cribrella sanguinolenta; Antedon Eschrichtii;

Een Spongia, een Hydroidenkolonie.

Station 49.

Pecten . grönlandicus; - - Nymphon hirtus ; Idotea bicuspida en Sabinei; Scalpellum sp. ; Polynoë sp.; nog een Annelide; - Eschara sp.; Flustra sp.; - Asterophyton sp. (fragmenten); Ophiacantha bidentata; Ophioglypha Sarsi en nodosa; Ctenodiscus crispatus; Archaster tenuispinus; - Spongia; Sertularia en 2 andere Hydroiden;

Station 50. Arm dierleven, hoofdzakelijk slechts Echinodermen.

Ascidia?; - Munnopsis typica (fragmenten);

'I'rochostoma boreale; Ophiacantha bidentata ; Ctenodiscus crispatus ; Cribrella sanguinolenta; Archaster tenuispinus; Antedon Eschrichtii; - een Spongia;

Station 51.

Molgula grönlandica; - Yoldia sp.; Leda pernula (schaalfragmenten); Pecten grönlandicus; Nymphon hirtus; Diastylis Rathkei en spinulosa; - Nereis zonata; - Polynoë sp.; kokers van 
Serpuliden e. a.; Nemertine; - Hornera lichenoides (talrijk); Hornera violacea; Flustra sp.; Eschara sp.; Crisia sp.; nog zes verschillende Kalkbryozoen; - Ophioscolex glacialis ; Ophiacantha bidentata; Archaster tenuispinus; Solaster furcifer; Cribrella sanguinolenta; Antedon Eschrichtii; 2 Spongiën; Sertularia sp.;

Station 52.

Astarte sp. (schalen); Yoldia sp.; Pecten gxönlandicus; -

Nymphon hirtus; nog een Pycnogonide; Diastylis Goodsiri; een Isopode; Scalpellum sp.; Nereis zonata; nog een Nereis sp.; Onuphis conchilega; Polynoë sp.; een Chaetopode; kokers, twee Nemertinen soorten; Planaria sp.; - Retepora sp.; Eschara sp.; Hornera lichenoides (fraaie groote stukken); Hornera violacea; Flustra membranaceo-truncata; nog 6 andere Bryozoen; Ophioscolex glacialis ; Ophiacantha bidentata ; Ophiura sp.; Archaster tenuispinus ; Solaster furcifer ; Cribrella sanguinolenta; - Spongia en Hydroidenkolonie;

Station 5 วิ.

Molgula grönlandica; - schalen van Gastropoden; Cardium sp.; Yoldia sp.; Leda pernula (schalen); Pecten grönlandicus; - Nymphon hirtus en een andere Pygnogonide; Diastylis spinulosa en Rathkei; Idotea Sabinei; Scalpellum sp.;

Nereis zonata; nog een Nereis sp.; 2 soorten van Polynoë; Pectinaria hyperborea (tuben); een Chaetopode; eenige tubicole Anueliden; kokers; Phasolosoma sp.; Planaria sp.; 2 sp. van Nemertinen; - Alcyonidium mammillatum; Hornera lichenoides en violacea; Crisia sp.; Flustra membranaceo-truncata; 6 andere Kalkbryozoen ; - Chiridota laevis ; Ophioscolex glacialis ; Ophiacantha bidentata; Ophiura sp.; Ctenodiscus crispatus; Archaster tenuispinus; Solaster furcifer; Cribrella sanguinolenta; - eenige Spongiën; Hydroidenkolonie;

Station 54.

Cylichna alba en nog een Gastropode; Leda pernula (schalen); Pecten grönlandicus; Idotea sabinei; - Nereis zonata; van Polynoë twee soorten; tuben van Pectinaria hyperborea en van Spiochaetopterus typicus; Chaetopode; Phascolosoma; - Alcyonidium mammillatum; Flustramembranaceo-truncata; Hornera lichenoides en violacea; nog een Kalkbryozoe;

Ophioscolex glacialis; Ophiacantha bidentata; Ophioglypha Sarsi ; Ctenodiscus crispatus (jeugdige exemplaren); Archaster tenuispinus; - 3 verschillende Spongien.

Station 55.

Yoldia sp.; Pecten grönlandicus; eieren van een Mollusk;

Nymphon hirtus; Diastylis spinulosa; Idotea Sabinei en bicuspida; nog een Isopode; Anonyx Wahlii ; - Nereis zonata en nog een Nereis sp.; Onuphis conchilega; kokers van Pectinaria hyperborea; Spiochaetopterus typicus; nog een Annelide; Phoscolosoma; een Nemertine; - Alcyonidium mammillatum; - Ophioscolex glacialis; Ophiacantha bidentata; Ophioglypha Sarsi en nodosa; Ctenodiscus crispatus; Archaster tenuispinus; Cribrella sanguinolenta; jonge Bekersponsen

Hydroidenkoloniën ;

Station 50. Rijke dregging.

Molgula crystalina ; - Pecten grönlandicus ;

Nymphon hirtus; Idotea bicuspida; Caprella echinata

Nereis zonata; Onuphis conchilega; Polynë sp.; tuben van Pectinaria hyperborea; Brada villosa; ecn Chaetopode; Phascolosoma sp.; Planaria sp,; een Nemertine;

Hornera lichenoides (talrijk); Flustra menibranaceo-truncata; Retepora sp. ; Eschara sp. ; Cellularia sp.; nog 2 Kalkbryozoen; - Chirodota laevis; Asterophyton Linckii; Ophioscolex glacialis : Ophiacantha bidentata (talrijk); Ophioglypha Sarsi; Ctenodiscus crispatus; Archaster tenuispinus ; Antedon Eschrichtii; - twee soorten van Hydroiden;

Station 57.

Een Gastropode; Yoldia en Leda pernula (schalen en schaalfragmenten); eieren van Lamellibranchiaten; - Nymphon hirtus en nog twee Pycnogoniden-soorten; Diastylis spinulosa; Idotea 
biscupida: Caprella echinata; Scalpellum sp.; - Glycera sp.; Nereis zonata; - Spiochaetopterus typicus; nog een kleine Annelide;

Hornera lichenoides en violacea; Eschara sp.; nog drie Kalkbryozoën; - Chirodota laevis; Ophioscolex glacialis; Ophiacantha bidentata; Ophioglypha Sarsi (fragmenten); Ctenodiscus crispatus; Archaster tenuispinus; Cribrella sanguinolenta; - een Spongia en een Hydroidenkolonie;

Station 58. Arme dregging; weinig dierleven.

Nymphon hirtus; nog een Pycnogonide; - Idotea bicuspida; Anonyx Wahlii; - Nereis virens; kokers van Spichaetopterus typicus; twee soorten van tubicole Anneliden; - Hornera sp.; nog een Kalkbryozoe ; Ophiacantha bidentata ; Ophioglypha Sarsi ; Ctenodiscus crispatus ; - Hydroidenkoloniën ;

Station 59.

Yoldia sp.; Leda pernula (schaalfragmenten); Pecten grönlandicus; - Nymphon hirtus ; Munnopsis typica (fragmonten); Idotea Sabinei; Scalpellum sp.; - Nereis sp.;. Onuphis conchilega; Polynoë sp.; Pectinaria hyperborea (kokers); ook kokers van Serpuliden e. a.; een Chaetopode; nog twee Anneliden; Phascolosoma;

Alcyonidium gelatinosum; Flustra membranaceo-truncata; Hornera lichenoidesviolacea; Eschara sp.; Crisia sp.; Cellularia sp, en nog vijf Kalkbryozoën;

Eupyrgus scaber; Asterophyton sp. (jeugdig ex.); Ophioscolex glacialis; Ophiacantha bidentata; Ophioglypha Sarsi; Hymenaster sp.; Ctenodiscus crispatus; Archaster tenuispinus;

Drie Hydroiden, o. a. Sertularia sp.; jonge Bekersponsen; nog een Spongia;

Station 60.

Astarte sp. (schaalfragmenten); Pecten grönlandicus; - Nymphon hirtus, waarbij ook een † met een nest jongen; Diastylis sp. (defect); Idotea bicuspida; - Glycera sp.; Polynoë sp. kokers van Pectinaria hyperborea e. a.; Phascolosoma sp.; Nemertine; Hornera lichenoides en violacea; Eschara sp.; Flustra membranaceo-truncata ; twee andere Kalkbryozoën ; - Asterophyton Linckii (jong ex.) ; Ophioscolex glacialis; Ophiacantha bidentata'; Ophioglypha Sarsi (fragmenten); Ctenodiscus crispatus; Archaster tenuispinus;

Drie verschillende Spongiae; Sertularia sp. en verscheidene andere Hydroiden Station 61.

'Astarte sp. (schaalfragmenten); Yoldia sp. (schalen); Pecten grönlandicus; - Nymphon hirtus; Diastylis Rathkei; Idotea Sabinei; Scalpellum sp.; - Nereis virens en zonata; nog een Nereis? sp.; Onuphis conchilega; twee soorten van Polynoë; Pectinaria hyperborea (kokers); een Chaetopode; nog een Annelide; Phascolosoma sp.; - Flustra sp.; Hornera sp.; Eschara sp.; nog 2 Kalkbryozoën ; - Chirodota laevis ; Asterophyton sp. (zeer jong ex.) ; Ophioscolex glacialis ; Ophiacantha bidentata; Ophioglyha Sarsi en nodosa; Ctenodiscus crispatus; Archaster tenuispinus ; -

Drie Spongiae; Sertularia's; - -

Station 62.

Molgula sp.; - Astarte sp. (schaalfregmenten); Yoldia sp.; - Pycnogonide; Diastylis sp.; Idotea Sabinei; - kokers van Pectinaria hyperborea; tubicole Annelide; een Chaetopode; Phascolosoma sp.; - Alcyonidium mammilatum; Hornera lichenoides en violacea; Eschara sp,; Cellularia sp.; nog een Kalkbryozoe; - Ophioscolex glacialis; Ophiacantha bidentata; Ophioglypha Sarsi ; Ctenodiscus crispatus; Archaster tenuispinus; - twee Hydroiden en drie Spongiën;

Station 63 .

Cylichna alba; Panopaea sp.; Astarte (schaalfragmenten); Yoldia sp.; Leda pernula (schalen); Pycnogonide; Nymphon hírtus, ook een $\sigma^{*}$ ex. met een nest jongen; Idotea Sabinei en bicuspida; een Amphipode; Balanus sp.; Scalpellum sp.; - Nereis zonata; Polynoë sp.; Pectinaria hyperborea (kokers) nog een tubicole Annelide; Phascolosoma sp.; - Hornera lichenoides en violacea; Flustra membranaceo-truncata; Eschara sp.; Cellularia sp.; nog een Kalkbryozoe; 
Trochostoma boreale; Ophioscolex glacialis; Ophiopholis aculeata; Ophiacantha bidentata; Ophioglypha Sarsii ; Ctenodiscus crispatus; Archaster tenuispinus; - Beker- en andere Sponsen; Hydroiden, o. a. Sertularia;

Station 64.

Een Gastropod; Panopaea sp.; Arca? sp.; Pecten grönlandicus; nog een Lamellibranchiaat en Molluskeneieren; -- Nymphon hirtus, ook een $\sigma^{*}$ met een nest jongen; Idotea Sabinei ; Anonyx Wahlii; Scalpellum sp.; - Glycera sp.; Pectinaria hyperborea; een Chaetopodensoort; Phascolosoma; - Alcyonidium gelatinosum en mammillatum; Hornera sp.; Flustra sp.; Eschara sp.; Crisia sp.; Celluleria sp.; nog een Kalkbryozoe; - Asterophyton eucnemis; Asterophyton sp. (zeer jeugdig ex.); Ophioscolex glacialis; Ophiacantha bidentata (zeer talrijk); Ophioglypha Sarsi (fragmenten); Ctenodiscus crispatus; Solaster tumidus; - Sertularia sp.; vier verschillende Spongiën;

Station 65.

Panopaea sp.; Pecten grönlandicus (schalen); nog een Lamellibranchiaat; - Nymphon hirtus ; Idotea Sabinei; Caprella echinata; Anonyx sp.; Amphipode (defect); Scalpellum sp.; - Nereis zonata; nog een Nereis sp.; Polynoë sp.; Pectinaria hyperborea (kokers); Brada villosa; Phasolosoma sp.; - Hornera lichenoides; Eschara sp.; Crisia sp.; Cellularia sp.;

Asterophyton Linckii; Ophioscolex glacialis; Ophiacantha bidentata (zeer talrijk); Ctenodiscus crispatus; Archaster tenuispinus; Solaster furcifer; Cribrella sanguinolenta;

Een Spongia en drie Hydroiden.

Station 66.

Een kleine Gastropode; Yoldia sp.; Pecten grönlandicus (schalen); Nymphon hirtus; Scalpellum sp.; - Nereis zonata; nog een Nereis sp.; Onuphis conchilega; 2 soorten van Polynoë; kokers van Spiochaetopterus typicus; een Chaetopode; een tubicole Annelide; twee Nemertinen sp.; Alcyonidium mammillatum; Hornera lich€noides en violacea, (de eerste zeer talrijk); Eschara sp.; Flustra sp.; Retepora sp.; Crisia sp.; Cellularia sp.; nog een Kalkbryozoe; - Chirodota laevis; Trochostoma boreale; Ophioscolex glacialis; Ophiacantha bidentata; Ophioglypha nodosa; Ctenodiscus crispatus; Archaster tenuispinus ; Solaster endeca; Cribrella sanguinolenta; - eenige Spongiën en Hydroiden, o. a. Sertularia sp.;

Station 67.

Panopaea sp.; Astarte sp. (schalen); Yoldia sp.; Pecten grönlandicus; Nymphon hirtus en nog een Pycnogonide ; Idotea entomon; Atylus coronatus; Caprella echinata; nog een Amphipode; Scalpellum sp.; - Nereis zonata; Onuphis conchilega; Polynoë sp.; Potamilla sp, ; kokers van Pectinaria hyperborea; Brada villosa; een Chaetopode; een kleine Annelide; een tubicole Annelide; Phascolosoma sp.; een Nemertine; - Alcyonidium mammillatum; Hornera lichenoides; Eschara sp.; Flustra sp.; Retepora sp.; Crisia sp.; - Eupyrgus scaber; Trochostoma boreale; Astero. phyton sp. (zeer jong ex.); Ophiacantha bidentata; Ophioglypha nodosa; Ophiura sp ; Ctenodiscus srispatus; Archaster tenuispinus.; - Sertularia en 2 andere Hydroiden; een Spongia;

Station 68. Crustaceëen geheel ontbrekend.

Gastropode (schaalfragmenten); Panopaea sp.; Astarte sp. (schalen); Yoldia sp.; - Nymphon hirtus; nog een Pycnogonide; - Nereis zonata ; Onuphis conchilega; Polynoë sp.; een Chaetopode; nog eenige Anneliden; kokers; Planaria sp.; - Alcyonidium mammillatum; Hornera lichenoides; Eschara sp.; Cellularia sp.; Flustra sp.; vijf andere Kalkbryozoën; - Ophiacantha bidentata (zeer talrijk); Ophioglypha Sarsi (fragmenten); Ctenodiscus crispatus; Ophiura sp.; - 3 soorten van Sponsen;

Station 69. Crustaceën bizonder talrijk; zeer rijke dregging.

Gastropode (schaalfragmenten); Panopaea sp.; Astarte sp. (schalen) ; Leda pernula ; - Nymphon hirtus; nog twee Pycnogoniden-soorten; - Sabinea septemcarinata; Crangon salebrosus; Hippolyte sp.; 2 Mysissoorten; Munnopsis typica (zeer talrijk, doch allen defect); Idotea Sabinei en entomon; Stegocephalus Kessleri; Acantostephia Malmgreni; Atylus carinatus; nog twee Amphi- 
poden; Scalpellum sp.; - Glycera sp.; Nereis zonata; Onuphis conchilega; Polynoë sp.; Potamilla sp.; Brada villosa; kokers van Spiochaetopterus typicus; een tubicole Annelide; Alcyonidium gelatinosum; Flustra sp.; Crisia sp. ; Cellularia sp.; nog een Kalkbryozoe; - Trochostoma boreale; Asterophyton Linckii; Ophioscolex glacialis; Ophiacantha bidentata; Ophioglypha Sarsi ; Ctenodiscus crispatus, Bekersponsen en twee andere Spongiae; Sertularia sp. e. a. Hydroiden; Hydroidpolyp;

Station 70.

Cynthia sp.; Molgula grönlandica; - eenige Gastropoden (schalen); Astarte sp. en Leda pernula (eveneens allen schalen); Molluskeneieren; - Nymphon hirtus en nog een Pycnogonidensoort; Sabinea septemcarinata; Crangon (salebrosus?); twee soorten van Hippolyte; Munnopsis typica; Idotea entomon; Stegocephalus Kessleri; AcanthostephiaMalmgreni; - Nereis zonata; Onuphis conchilega; twee soorten van Polynö̈; een Chaetopoden-soort; een tubicole Annelide; Eschara sp.; Retepora sp.; Hornera sp.; Flustra sp.; 3 andere Kalkbryozoen; - Trochostoma boreale; Ophioscolex glacialis; Ophiacantha bidentata; Ophioglypha Sarsi ; Ctenodiscus crispatus; Pteraster militaris; Solaster tumidus; Actinia sp.; 2 Spongiën; Hydroidpolyp en 2 Hydroiden. koloniën ;

Station 71. Zeer arme dregging.

Leda pernula; - Idotea biscupida; Stegocephalus Kessleri;

Polynö sp.; een Nemertine; - Trochostoma boreale; Ophiacantha bidentata; Ctenodiscus. crispatus ; - een Spongia;

Station 72.

Cylichna alba; schalen van Tellina lata en Astarte sp.; Arca glacialis; - een Pycnogonide; 2 soorten van Mysis; Munnopsis typica (fragmenten); Acanthostephia Malmgreni nog een Amphipode; Scalpellum sp.; Glycera sp.; Nereis zonata; Nereis sp.; tubicole Anneliden;

2 soorten van Flustra; Eschara sp.; Crisia sp.; Chirodota laevis; Eupyrgus scaber; Ophiacantha bidentata; Ophioglypha Sarsi en nodosa; Ctenodiscus crispatus; - een Spongia en een Hydroidpolyp;

Station 73.

Schalen van twee Gastropoden-soorten, van Tellina lata en van een Astarte sp.; Yoldia sp.; Leda pernula; Arca glacialis; - Idotea Sabinei; Nereis zonata; nog een Nereis sp.; Onuphis. conchilega; Polynoë sp.; Brada villosa; een Chaetopode; eenige Anneliden en enkele kokers; Alcyonidium sp.; Hornera lichenoides en violacea; Crisia sp.; Cellularia sp.; Retepora sp.; Flustra sp.; Eschara sp.; vijf andere Kalkbryozoën; - Ophiacantha bidentata; Ophioglypha Sarsi (fragmenten); Ctenodiscus crispatus; een Spongia; twee Hydroiden en een Actinia sp.; Station 74.

Cardium sp.; Yoldia sp.; Leda pernula (schaalfragmenten); Arca glacialis; Nymphon hirtus nog eeen Pycnogonide; - een Amphipode;

Nereis sp.; 2 soorten van Polynoë; kokers van Amneliden; - Retepora sp.; Crisia sp.; Cellularia sp.; Eschara sp.; Hornera lichenoides en violocea; nog twee andere Kalkbryozoën ; Ophioscolex glacialis; Ophiacantha bidentata; Ophioglypha Sarsi; Cribrella sanguinolenta; een Asteride; Antedon Eschrichtii; - Bekerspons en nog en Spongia;

Station 75.

Yoldia sp.; Arca sp.; eieren von Mollusken; - Nymphon hirtus; Idotea Sabinei en entomon ; - 2 soorten van Polynoë; Potamilla sp.; Chaetopoden-soort; zeer talrijke kokers van Serpuliden enz.; - Eschara sp.; Hornera lichenoides en violacea; Crisia sp.; Cellularia sp.; Retepora sp.; nog 2 Kalkbryozoën; -- Ophioscolex glacialis; Ophiacantha bidentata (zeer talrijk); Ophioglypha Sarsi; Solaster papposus; - een Spongia;

Station 76.

Glycera sp.; kleine Annelide; - Ophioglypha Sarsi; 


\section{Station 77.}

Cardium sp: ; Leda pernula; Pecten grönlandicus ; -

Nymphon hirtus; Pynogonide; Crangon (salebrosus?); 2 soorten van Hippclyte; Munnopsis typica (talrijk); Idotea Sabinei; Acanthostephia Malmgreni; Anonyx pumilus; - 2 soorten van Glycera; Eschara sp.; Cellularia sp.; nog 2 Kalkbryozoën; - Ophiacantha bidentata; Ophioglypha Sarsi; Hymenaster sp.; - Actinia sp.; eenige Hydroidpolypen; een Hydroidenkolonie;

\section{Station 78.}

Leda pernula; Arca glacialis; Pecten grönlandicus; - Munnopsis typica; Idotea Sabinei ; Anonyx pumilus; Glycera sp.; wormkokers; - Crisia sp. en nog een Kalkbryozoe; - Ophiacantha bidentata; Ophioglypha Sarsi; - een Spongia en een Hydroidpolyp; -

\section{Station 79.}

Leda pernula; Arca glacialis ; -Diastylis sp.; Idotea Sabinei; kleine Amphipode; Scalpellum sp.; - Glycera sp.; Chaetopode ; Hirudinee?; een Annelide ; eenige kokers ; - Alcyonidium sp.; Flustra sp. (talrijk); Eschara sp.; Crisia sp.; Cellularia sp.; Chirodota laevis; Ophioscolex glacialis; Ophiacantha bidentata Ctenodiscus crispatus; een Spongia en een Hydroidenkolonie; -

\section{Station 80.}

Astarte sp. (schaalfragmententen); Leda pernula; Arca glacialis ; Mytilus (schaal); Pecten grönlandicus; - kokers van Spiochaetopterus typicus e. a. wormen; - Alcyonidium gelatinosum ; Flustra membranaceo-truncata (talrijk); nog een Flustra sp.; Crisia sp.; Eschara sp.; Hornera sp. ; nog een Kalkbryozoe ; - Chirodota laevis ; Trochostoma boreale ; Ophioscolex glacialis ; Ophiacantha bidentata; Ophioglypha nodosa; - Sertularia sp.; Bekersponsen; -

\section{Station 81 .}

Buccinum sp.; Leda pernula; Arca glacialis; Pecten grönlandicus (zeer talrijk); - Nymphon hirtus; Sabinea septemcarinata; Crangon salebrosus; 2 soorten van Hippolyte; Munnopsis typica (talrijk, maar allen defect); Acantostephia Malmgreni; Stegocephalus Kessleri; Atylus carinatus (fagmenten); nog een Amhipode; - Glycera sp. (talrijk); een Annelide; kokers; Alcyonidium gelatinosum; Flustra sp.; Eschara sp.; Crisia sp.; nog een Kalkbryozoe ; - Trochostoma boreale; Ophioscolex glacialis; Ophiacantha bidentata; Ophioglypha Sarsi ; - Actinia sp.; een Spongia ; een Hydroidpolyp; -

Station 82.

Leda pernula; Pecten grönlandicus (talrijk); - Nymphon hirtus; Pycnogonide ; - Munnopsis typica (defect); Acanthostephia Malmgreni; nog een Amphipode ; - Glycera sp.; Polynoë sp.; kokers; - Flustra membranaceo-truncata; Eschara sp.; twee Kalkbryozoën; - Ophioscolex. glacialis; Ophiacantha bidentatá; Ophioglypha nodosa en Sarsi; Hymenaster sp.; Antedon Eschrichtii (zeer jong exemplaar, nog met petiolus); 1 Spongia; Hydroidenkolonie; Hydroidpolyp ; -

Station 83.

Buccinum (schaalfragmenten); Astarte sp.; Nymphon hirtus; nog een Pycnogonide; Crangon (salebrosus ?); Hippolyte sp.; ook een $\$$ met eieren; Diastylis scorpioides; Munnopsis typica; Atylus carinatus ; nog een Amphipode; - Onuphis conchilega ; kokers ; - Flustra membranaceotruncata ; Eschara sp.; Hornera lichenoides ; Crisia sp.; Cellularia sp.; - Ophioscolex glacialis; Ophiacantha bidentata; Ophioglyha Sarsi en nodosa ; Archaster tenuispinus; een Hydroidpolyp. 
VII. Systematisch Overzicht.

DER

\title{
VOORNAAMSTE SOORTEN EN GESLACHTEN,
}

met opgave der verschillende Stations, warop ze werden aangetroffen.

\section{Tunicata. \\ ASCIDIAE.}

Cynthia Sav. sp. 70 .

Molgula crystalina. $34,38,48,56$.

Molgula grönlandica. $31,43,48,51,53,70$.

\section{Mo 11 us c a.}

\author{
GASTROPODA.
}

B u c c in u m L. sp. 2, 14, 81, 83 .

Cylichna alba Brown.' 54, 63, 72.

Dendronotus arborescens. 2 .

\section{LAMELLIBRANCHIATA.}

Siphoniata.

S axicava pholadis L. $1,11,22$.

P a n o p a e Mén. LA GR. $s p . \quad 2,3,9,11,17,63,64,65,67,68,69,72$.

Tellina la a Gmímin. $1,10,11,12,14,15,19,21,22,27,44$.

Astart.e Som. sp. 1, 2, 9, 10, 11, 12, 14, 15, 17, 19, 21, 22.

Astarte Som. sp. 1 .

Cyprina islandica Lan. 2.

Cardium I. sp. 1,2 .

\section{Asiphonia.}

Yold i a MöLL. sp. $38,51,52,53,55,59,63,66,67,74,75$

L e d a p e rnu la Müller. 1, 9, 10, 11, 21, 23, 24, 33, 37, 40, 69, 71, 72, 77, 78, 79, $80,81,82$.

Arca (glacialis Gray?). $64,72,73,74,75,78,79,80,81$.

Mytilus L. sp. So.

Pecten grönland i cus Sowerby. 22, 23, 24, 28, 30, 34, 35, 36, 37, 38, 39, 40,41, $42,43,45,46,48,49,51,52,53,54,55,56,59,60,61,64,66,67,77,78$, $80,81,82$. 


\section{Arthropoda.}

\section{ARACHNOIDEA.}

Acarina.

Nymphon hirtus Fabr. 5, 9, 10, 15, 17, 23, 24, 25, 26, 27, 29, 29, 32, 34, 35, 36, $38,39,41,45,46,47,48,49,51,52,53,55,56,57,58,59,60,61,63,64,65$, $66,67,68,69,70,74,75,77,81,82,88$.

\section{CRUSTACEA.}

Thoracostraca.

H y a s a ra e a L. 2.

Pagurus Fabr. sp. 1, 2.

Sabinea septemcarinat a SAB. $1,17,69,70$.

Crangon boreas Perpps. 2, 5, 34.

Crangon salebros us Owes. $69,77,81,83$.

M y s i s Latr. $s p .23,27,48,69,72,82$.

Diastylis Goodsiri Bet.s. $45,52,60,62$.

Di a stylis Rathkei Krörer. $48,51,53,61$.

Di a s ty 1 is s p in ul o s a Hellek. $25,36,40,42,44,46,51,53,55,57$.

Di a stylis scorpioides Lepechin. $39,45,83$.

\section{Arthrostraca.}

ISOPODA.

M u n n o psis ty pi c a M. Sars. 10, 17, 18,22, 23, 27, 28, 32, 34, 35, 40,44, 45, 46, $48,50,59,69,70,72,77,78,81,82,83$,

I d ote a bi s c up i d a Owen. 23, 24, 25, 26, 28, 47, 49, 55, 56, 57, 58, 60, 63, 71.

I d otea tintomon L. $10,13,16,32,38,44,67,69,70,75$.

I d o t e a S a b i n e i Krörer. $10,14,15,17,20,25,30,32,34,35,36,38,39,40,41,42$, $48,44,45,47,48,49,53,54,55,59,61,62,63,64,65,69,73,75,77,78,79,80$.

\section{Amphipoda.}

Stegocephalus Kessleri. $69,70,71,81$.

A canthostephia Malmgreni Goüs. 1, 2, (6?), 10, 17, 69, 70, 72, 77, 8182.

A n o n y x la ge n a Krökrr. 1, 2, 10, 11, 17, 22, 25, 28, 29, 34, 44, 47, 48.

A non yx pumilus Lilljeborg. 20, 23, 77, 78.

Anonyx Wahlii. 23, 43, 47, 55, 58, 64.

Atylus carin at us Fabricius. 23, 67, 69, 81, 83 .

Caprella e chinata. $8,25,39,45,56,57,65,67$.

\section{Copepoda.}

Caligus O. Fr. Müller sp. Fjorden van Norwegen.

Ca lan.us Leach $s p$. 21, 23, 26, 48.

\section{Cirripedia.}

B a l a n u s List. sp. $1,2$.

S c a l p e $11 \mathrm{u}$ m LEACH $s p . \quad 20,21,24, .27,30,32,34,37,39,39,40,41,48,49,52,53$ : $57,59,60,61,63,64,65,66,67,69,72,79,80$. 


\section{Vermes.}

\section{ANNELIDES.}

Chaetopodes.

\section{Polychaetal.}

Errantia.

G ly cera SAv. sp. $10,11,17,33,37,44,57,64,69, .72,76,77,79,79,80,81,82$.

N e r i s virens Malmgen. $19,39,45,58,61$.

$\mathrm{N}$ e r e i s z o n a t a Malmgen. $1,2,21,23,24,27,23,31,38,39,42,43,45,46,48,51$, $52,53,54,55,56,57,61,63,65,66,67,68,69,70,72,73$.

E un ice Cuv. sp. 19, 20, 21, 22.

Onuphis conchilega M. SArs. $26,28,39,41,52,55,56,59,61,66,67,68,69$, $70,73,83$

$$
\mathrm{S} \text { e d e n t a r i a. }
$$

Pat a milla Malmar. sp. 1, 10, 20, 21, 26, 67, 69, 75, 80 .

Pectinaria hy e r b o e a Malmgur. $10,11,18,19,20,21,22,23,36,64$.

B rada villos a Rathкx. $25,56,65,67,69,73$.

S piochaetopter u s ty p ic u s M. Sars. $1, .48,54,55,57,58,66,69$.

Ophelia SAv. sp. 22 .

A motrypane an logas ter RAthks. $10,12,16,37$.

\section{GEPHYREI.}

Phascolos om a (boreale?) Ker. 17, 20, 21, 22, 23, 24, 26, 27, 36, 37, 38, 39, 41, $42,44,45,53,54,55,56,59,60,61,62,63,64,65,67$.

\section{PLA'IYHELMINTHES}

Turbellaria.

Planaria O. Fr. MüLL sp. 41, $5253,56,68$.

\section{BRYOZOA.}

Stelmatopoda.

Chilostomata.

Retepora cellulosa L. $25,26,36,37,38,39,40,48,52,56,66,67,70,73,74,75$. Es ch a r a RaY $s p . \quad 22,24,25,26,27,28,29,31,32,33,34,35,36,37,38,39,40,41$, $42,43,45,46,47,49,51,52,56,57,59,60,61,62,63,64,65,66,67,68,70$, $72,73,74,75,77,79,80,81,82,83$.

Flustra membran a ce o-tru n a t a Smrrr. 1, 5, 11, 14, 20, 12, 24, 25, 26, 27, 30, 31, 32, 33, 34, 35, 36, 37, 39, 39, 40, 41, 42, 45, 47, 45, 49, 51, 52, 53, 54, 56, $59,60,61,63,64,65,66,67,68,69,70,72,73,79,80,81,82,83$.

Gemellaria Sars $s p .60,64,65,67,70,73,77$.

Ce 11 u la ri a Pallus sp. 56, 59, 62, 63, 64, 65, 65, 66, 68, 69, 73, 75, 77, 79, 83.

\section{Ctenostomata.}

Alcyonidium gelationosum L. 1, 3, 9, 10,11, 12,13,14,15, 19, 20, 21, 28, $44,59,64,69,80,81$. 
A l cionidi um m a m mill a tu m ALDer. 1, 5, 22, 38, 39, 42, 48, 53, 54, 55, 62, 64, $66,67,68,73$.

\section{Cyclostromata.}

Hornera 1 i chenoides L. $1,24,25,26,28,29,31,33,34,35,36,37,38,39,40$, $41,42,43,45,46,48,51,52,53,54,56,57,58,59,60,61,62,63,64,65,66$, $67,68,70,73,74,75,83$.

Horne ra viol a e a M. SARs. $40,41,42,48,51,52,53,54,57,59,60,62,63,66$, $73,74,75$.

Crisia eburnea L. $45,48,51,53,59,64,65,66,67,69,72,73,74,75,77,78,79$; $80,81,83$.

\section{Fchinodermata.}

\section{HOLO'THURIOIDEA.}

Chirodota laevis FABR. 53, 56, 57, 61 66, 72, 79, 80 .

E u p yrgu s s c. a b e.r Lürken. $59,67$.

Trochostoma boreale. $3,5,6,9,10,12,14,15,16,17,19,20,21,22,23,26,27$, $30,33,34,39,41,42,44,50,63,66,67,69,70,71,80,81$.

\section{ECHINOIDEA.}

Echinus L. sp. 2.

\section{AS'IEROIDEA.}

\section{Ophiuridea.}

Euryaleae.

A sterophyton e u c n e mis Müller \& 'Troscher. 1, 15, 24, 64. A sterophyton Linckii. $10,23,38,42,45,46,56,60,65,69$.

\section{Ophidreak.}

O p hi o s c olex gla ci a is Müllek \& 'Iroschel. 1, 24, 25, 26, 27, 31, 32, 34, 35, 36, $37,38,39,40,41,42,43,44,45,46,47,48,51,52,52,54,55,56,57,59,60$, $61,62,63,64,65,66,69,70,74,75,79,80,81,82,83$,

Ophiopholis a cul e a t a Müller. 1, 63.

O phioc an tha bi de ntat a Rerzius. $1,5,8,9,10,11,13,14,15,16,17,18,19,20$, $22,23,24,25,26,27,28,29,31,32,33,34,35,36,37,38,39,40,41,42,43$, $44,45,46,47,48,49,50,51,52,53,54,55,56,57,58,59,60,61,62,63,64$, $65,66,67,68,69,70,71,72,73,74,75,77,78,79,80,81,82,83$.

O p hi ogly p ha S a r s L Lürken. 9, 14, 15, 16, 17, 18, 20, 2i, 22, $23,24,25,26,27$, $28,29,30,31,32,33,34,37,38,39,43,44,45,47,48,49,54,55,56,57,58$, $59,60,61,62,63,63,64,68,69,70,72,73,74,75,76,77,78,81,82,83$.

O p h i o gly p ha nod o s a Lürken. $1,17,26,31,34,35,36,40,41,43,48,49,55,61$, $66,67,72,80,82,83$.

Ophiogly pha (robusta?) Arres. 1.

O phi u r a Lam. $s p$. 52, 53, 68. 


\section{Asteridea.}

H y menaster $s p . \quad 26,59,77,82$.

Cten od is cus cris pat u Retzius. $1,5,8,10,11,12,14,15,16,17,19,20,21,22$, $23,24,25,26,27,28,29,31,32,34,35,36,37,38,39,41,42,43,44,45,46$, $47,48,49,50,53,54,55,56,57,58,59,60,61,62,63,64,65,66,67,68,69$, $70,71,72,73,79$.

Archaster ten uispinus Düben \& Koren. 8, 9, 21, 24, 25, 26, 27, 28, 29, 31, 32 , $33,34,35,36,37,38,39,40,41,43,44,45,46,47,48,49,50,51,52,53,54$, $55,56,57,58,60,61,62,63,65,66,67,68,83$.

Pteraster militaris MüLler. 70.

Solaster endeca Retz. 66.

Solaster furcifer Düben \& Koren. $36,38,46,51,52,53,65$.

Solaster papposus L. 75.

$\mathrm{S}$ olaster tumidus Stuxb. $34,46,64,70$.

Pedicellaster typicus M. Sars. 10.

Cribrella sangninolenta O. F. Müller. 24, 25, 26, 28, 31, 32, 34, 35, 39, 40, $42,43,44,45,46,47,48,50,51,52,58,55,57,65,66,74$.

He liaster Grax. sp. 1 .

\section{CRINOIDEA.}

Antedon Eschrichti i J. Müller. 18, 25, 26, $35,37,38,41,45,48,50,51,56,74, \$ 2$.

\section{Coelenterata.}

\section{HYDROMEDUSAE.}

Hydroidea.

S e r tu laria L. sp. $9,49,51,59,60,61,63,66,67,69,80$.

P I u m u I a i a Lam. sp. 3, 45, 46. 48, 49, 55, 56, 57, 59, 60,61, 62, 63, 65, 66, 67, 69 $70,73,79,80,82$. 


\section{Iets over het algemeen karakter van de Fauna op den bodem van de Karazee.}

Het feit, dat ik slechts een klein gedeelte der Karazee als het terrein mijner onderzoekingen kan aanwijzen, heeft naast het nadeel, dat ik daardoor geen nieuwe gegevens heb kunnen verzamelen, voor de kennis van de fauna dezer zee in haar geheel beschouwd, toch ook zijn voordeelen, hetgeen uit het hier volgende blijken zal.

Al wat wij tot nu toe van de fauna dezer streken wisten, zijn wij verschuldigd aan de onderzoekingen der Zweedsche expeditiën,' in de jaren 1875, 1876 en 1878/79 ondernomen, waarvan de resultaten zijn saamgevat in een bijdrage van Dr. ANTon Sruxberg, getiteld: »Evertebrat. faunan i Sibiriens Ishaf.« Stockholm 1882. In het laatste hoofdstuk van deze bijdrage (1. c. p. 773), dat de vraag behandelt in hoeverre wij voor het oogenblik de Evertebratenfauna der Siberische IJszee kennen, spreekt de schrijver zeer beslist de meening nit dat, ofschoon het aantal dreggingen, in het oostelijk gedeelte dezer zee gedaan, aanzienlijk kleiner is, dan dat, hetwelk in het westelijk gedeelte werd ondernomen, het toch dit laatste is, waarmede wij nog het minst bekend zijn ${ }^{1}$ ) Dit verklanrt zich door de groote eenvormigheid in het oostelijk gedeelte, wat aangaat diepte of bodemsgesteldheid, waarvan een geringe afwisseling in het dierleven natuurlijk het gevolg is. Geheel anders daarentegen is het gesteld met de westelijke helft der Siberische IJszee, en wel voornamelijk met haar meest westelijk gedeelte, dus de Karazee, in engeren zin, waar grootere verschillen in diepte en bodem een veel eigenaardiger en afwisselender dierleven ten gevolge hebben.

Het door mij ingestelde onderzoek van den bodem der zee beperkt zich nu wel tot een slechts kleine uitgestrektheid, maar dit terrein valt voor verreweg het grootste gedeelte in het door Struxberg bedoelde, diepere deel der Karazee, en bovendien had dit onderzoek door het groot aantal dreggingen zulk een volledigheid bereikt, als met de hulpmiddelen, waarover ik te beschikken had, en de omstandigheden waaronder ik verkeerde, slechts eenigszins mogelijk was.

De resultaten die ik verkreeg, zijn, om zoo te zeggen, meer van negatieven dan van positieven aard; immers ik kan weinig toevoegen aan hetgeen door STuxberG in zijn bovengenoemd geschrift werd medegedeeld, maar wel ben ik in staat orn met zekerheid een aantal gevolgtrekkingen, door hem gemakt, vooral wat aangaat de verspreiding en het meer of minder talrijk voorkomen van vele diersoorten in deze streken, te wijzigen, aan te vullen of naar mijn bevinding voor onjuist te verklaren. En dit kan geen verwondering baren, wanneer ik hier herhaal, wat ik reeds boven terloops aanmerkte, dat namelijk binnen de grenzen van dit gebied op niet meer dan slechts drie plaatsen door de Zweden werd gedregd. Zoo zijn er, om iets te noemen, verscheidene soorten, die door Sruxberg in 't geheel niet in de Karazce werden gevonden, en wier westelijke grens hij daarom veel te ver oostwaarts aanneemt, daar ze door mij aldáár wel werden aangetroffen. Voor andere soorten vind ik zeer belangrijke verschillen met Sruxberg, wat angaat de relatieve veelvuldigheid van hun voorkomen; voor nog anderen heb ik groote afwijkingen waargenomen met betrekking tot de diepte, waarop ze door den Zweedschen onderzoeker werden aangetroffen, en zoo voort.

Ik meen niet beter te kunnen doen, dan achtereeuvolgens van die vormen, waarvan ik volkomen zeker ben, op te geven, waarin de omstandigheden waaronder en de plaats, waarop ik ze vond, verschillen van die, welke Stuxberg aangeeft, hetgeen dus in verband met de in de vorige hoofdstukken opgenomen bijzonderheden aanleiding geeft tot de volgende beschouwingen.

1) Ik wil hier nogmaals herinneren, dat STuxberg àe geheele Siberische IJszee verdeelt in twee deelen, een westelijk deel, de Karazee, die hij aanneemt dat zich oostwaarts uitstrekt tot Tajnyrland, en een oostelijk deel, van cáár tot aan de Behringistraat. 
Wenden wij ons in de eerste plaats tot de vijf diersoorten, die STUXBERG vooraf afzonderlijk. bespreekt ${ }^{1}$ ), als zijnde de meest karakteristieke vormen der Siberische IJszee, namelijk: I do tea Sabinei, Idotea entomon, Diastylis Rathkei, Atylus carinatus en Acanthostephia Malmgreni.

Deze treden met uitzondering van de eerstgenoemde soort, waarover later, geenszins op als. kenmerkend voor de fauna van het door mij onderzocht gedeelte der Karazee. I d o te a e n tomon toch werd slechts op 10 , Diastylis Rathkei op 4, Atylus.carinatus op 5 en. A canthostephia $\mathrm{Malmgreni}$ op 9 van de 83 stations gevonden, en allen telkens in zeerweinige exemplaren.

I d o te a e n t o mo n werd door mij waargenomen tusschen 58 en 76 vaâm, en daar dit een veel aanzienlijker diepte is dan die, waarop de genoemde diersoort volgens STuxberg het talrijkst wordt aangetroffen (4-20 vaâm), moge dit het feit verklaren, dat dit dier volstrekt niet tot. de karakteristieke soorten der. Karazee behoort. Nu zegt Stuxberg verder, dat hij meent te mogen aammemen, dat »daar waar I dote a entomon voorkomt, zij in onvergelijkelijk grooter aantal optreedt dan ooit met I d ote a $\mathrm{S}$ abinei het geval is, hetzij ze geschoiden, hetzij ze te zamen worden aangetroffen $\ll$. Ik vond geheel het tegenovergestelde: van de 10 stations, waarop ik Idotea entomon vond, waren er vijf waarop zij allén en vijf waarop zij gelijktijdig met. haar zustervorm voorkwam, maar altijd was zij slechts door enkele individuen vertegenwoordigd, terwijl Idotea Sabinei in veel talrijker exemplaren aanwezig was. De door StuxberG voor de geheele Siberische IJszee vastgestelde regel geldt dus zeker niet voor het door mij onder-. zocht gedeelte der Karazee.

Diastylis Rathkei behoorde tot de zeldzame dieren, daar zij slechts vier keeren werd gevonden, en wel op 44, 47, 55 en 78 raâm diepte, zoodat de grenzen, die Stuxberg voor haarvoorkomen stelt, namelijk 3-60 vaâm, nog wat ruimer kunnen genomen worden; de exemplaren toch, die ik op 78 vaâm diepte vond, waren geheel normaal en in niets van de op geringere: diepte gevonden individuen te onderscheiden. Het dier werd twee malen in gezelschap van I d o tea $\mathrm{S}$ abinei en twee malen zonder deze aangetroffen, maar met I do tea entom on kwam zij nooit gelijktijdig voor. Deze verbazende talrijkheid, waarmede de soort volgens STUX-. BERG optreedt daar, waar zij voorkomt, geldt in dit gedeelte der Karazee evenmin als yoor Id o tea e n t o mon, daar zij even als deze laatste soort steeds in zeer weinige exemplaren werd aangetroffen.

Talrijker nog dan Diastylis Rathkei was Diastylis spinulosa, die tenminste op. 10 verschillende stations werd gevonden.

Atylus carinatus werd vijf maal angetroffen, maar eveneens altijd op grootere diepte dan, waarop Stuxberg meent dat hij voorkomt. Deze toch vond hem gewoonlijk tusschen 3 en 20 vaâm, en ofschoon hij hem één enkele keer op 60 vaâm aantrof, gelooft hij toch niet, dat hij op zulk een diepte zal leven, maar meent veeleer te moeten aannemen, 》dat hij daar door een toevallige samenvoeging van diersoorten van verschillende plaatsen is gekomen«. Deze toevalligheid schijnt echter te verdwijnen wanneer ik naga, dat ik zeer fraaie levende exemplaren der bedoelde soort vond op 59, 66, 69 en zelfs op 73 vâtm, zoodat men gerust mag aannemen, dat A tylus carinatus zich niet tot den zoogenaamden sublitoralen gordel beperkt ( $3-20$ vaâm), maar zich ook'daar beneden, zij het dan ook minder talrijk, tot in den elitoralen gordel verspreidt. Zooals STuxberg trouwens zelf opgeeft, werd hij op de Westkust van Noorwegen door prof́. LILLJeborG op 40-50 vaâm gevonden, zoodat het niet goed te verklaren zou zijn, waarom hij in de Siberische IJszee de 20 vaâm niet zou overschrijden.

Wat eindelijk aangaat Acanthostephia Malmgreni, een echt arktische vorm, die nog;

1) 1. c. p. 715 en verv. 
nooit buiten de grenzen der IJszee-fauna werd aangetroffen, deze werd door Stuxberg eveneens voornamelijk in den sublitoralen gordel gevonden, terwijl zij door mij werd verzameld tot op één na de grootste diepte, waarop ik in de Karazee gedregd heb, namelijk op 94 vaâm, alwaar geen der andere bovengenoemde diersoorten meer voorkwam. In 't geheel vond ik haar in de Karazee 9 maal, op diepten afwisselend tusschen 66 en 94 vaâm.

Zien wij dus uit het bovenstaande, dat vier van de vijf door STUxbERG opgegeven karakteristieke diervormen hier niet als zoodanig optreden, dan doet zich als van zelven de vraag voor, welke diersoorten dan wèl als kenmerkend voor de fauna dezer streken moeten worden beschouwd. Als antwoord op deze vraag moet $i k$ in de eerste plaats aanmerken, dat de groep van dieren die volgens mijne ondervinding het bedoelde gedeelte der Karazee karakterisecrt, niet die der C r ust a c e ë n, maar die der Echinodermen is. Wel is het aantal soorten der eerstgenoemden eenigszins grooter dan dat der laatstgenoemden, máar daar men bij de bepaling, of een soort al of niet tot de kenmerkende eener fauna behoort, toch in de eerste plaats het oog heeft te houden op de omstandigheden, of $\mathrm{zij}$ in het gebied dier fauna algemeen verspreid voorkomt, en bovendien of zij daar, waar zij optreedt in individuenaantal de haar vergezellende soorten meer of minder ver achter zich lat, zoo kan het niet geloochend worden, dat het aantal van dergelijke soorten voor $\mathrm{E}$ chin o d e r m en geheel op den voorgrond komt, zoowel wat aangaat het aantal stations waarop, als het aantal exemplaren waarin de bedoęlde soorten werden angetroffen. Om dit nader toe te lichten behoeft men slechts de andacht te vestigen op het op p. 39 en verv. gegeven systematisch overzicht. Hierin toch zien wij, eenige Bryozoën en Nymphon hixtus buiten rekening latende, dat het slechts 'Echinodermen zijn, die op een zeer groot aantal stations gevonden zijn.

In de eerste plaats is het briten allen twijfel waar, dat het algemeenste dier, dat in dit gedcelte der Karazee 'voorkomt, $\mathrm{Ophi}$ a cantha bidentata is; niet alleen trof ik het op 74 stations aan, maar ook kwam het in de meeste gevallen in een zeer groot, ja somtijds bijna ongeloofljjk groot aantal voor; zeer dikwijls waren de zwabbers met honderde exemplaren dezer species bedekt en kon men op het eerste gezicht slechts eenige weinige andere soorten ontdekken. 'l'egelijkertijd was dit de oorzaak van het zonderlinge doch fraaie schouwspel, dat de pas opgehaalde zwabbers, in de duisternis gebracht, op ontelbare punten een zacht groen licht uitstraalden, hetgeen echter zelden lang duurde, daar de dieren meestal spoedig stierven. O p h i ac a 11 th a was door haar overgroot aantal een der vervclendste en hinderlijkste species, die men zich bij het verzamelen denken kan. Zij kwam op zeer verschillende diepten voor, daar ik haar zoowel op 44 en 94 als op alle daartusschen liggende diepten aantrof.

Dcze feiten stemmen overigens vrij wel overeen met hetgeen, door Sruxbsks werd waargenomen. Deze toch geeft als een der plaatsen, waar hij een fauna aantrof, die hij met den naam Ophiacantha-formatie bestempelt, een gedeelte der zee tusschen Waaigat en het schiereiland Jalmal, met zuiveren leembodem en een diepte tusschen 50 en 90 vaâm. Uit mijn gegevens blijkt, dat deze formatie zich nog belangrijk verder noord- en oostwaarts uitstrekt.

Andere, eveneens zeer talrijke Echinodermen waren Ctenodiscus crispatus, Ophioglyphasarsi, Ophioscolex glacialis en Archaster tenuispinus, terwijl eerst na alle deze soorten een $\mathrm{Crustacee,} \mathrm{nl.} \mathrm{Id} \mathrm{otea} \mathrm{Sabinei,} \mathrm{in} \mathrm{aanmer-}$ king komt.

Ctenodiscus cuispatus kwam niet zó dikwijls als Ophiacantha bidentata, en ook niet in zulke tallooze exemplaren voor, maar behoorde toch ontegenzeggelijk tot de algemeenst voorkomende diervormen. Hij werd aangetroffen op 61 stations, en op diepten afwisselend tusschen 50 en 94 vaâm.

Ophiogly pha Sarsi vond ik. op 54 stations, op diepten afwisselend tusschen 50 en 94 vaâm, doch ze werd door mij niet ten zuiden van den $71^{\text {sten }}$ breedtegraad aangetroffen.

Ophi os c olex glaciali s vond ik op 46 verschillende plaatsen op diepten tusschen 44 en 88 vâm. 
Het verdient opmerking, dat deze soort voor de eerste maal op station $24\left(71^{\circ} 20^{\prime} \mathrm{N}\right.$. B., $64^{\circ} 54^{\prime}$ O. L.) werd aangetroffen, zoodat zij in het zuidoostelijk gedeelte van het door mij onderzochte deel der Karazee niet of slechts weinig schijnt voor te komen.

Eindelijk Archaster tenuispinus. Deze soort trad, wanneer zij voorkwam, gewoonlijk in zeer talrijke exemplaren op, ten zuiden van $71^{\circ} 20^{\prime}$ evenwel kwam zij slechts hoogst zelden voor, zoodat zij in de reeks der dreggingen bijna uitsluitend tusschen de stations 24 en 68 werd waargenomen, en dus gelijktijdig met de vorige species verscheen, doch veel eerder weêr verdween. Tusschen de twee genoemde stations liggen er slechts 4 waar A r chaster ten $\mathrm{u}$ is pinus niet werd aangetroffen, terwijl hij in 't geheel op 45 plaatsen en tusschen 44 en 88 vaâm diepte gevonden werd.

De volgende tabel geeft een overzicht van de verspreiding der vijf hier besproken Echinodermen, over het gebied tusschen de stations 8-83, terwijl de bijvoeging der diepten het mogelijk maakt de vertikale verspreiding dezer soorten na te gaan.

\begin{tabular}{|c|c|c|c|c|c|c|c|c|c|c|c|c|c|}
\hline 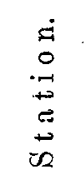 & $\begin{array}{l}\dot{0} \\
\overrightarrow{0} \\
\dot{0} \\
\ddot{a}\end{array}$ & 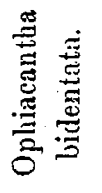 & 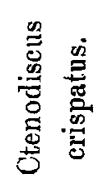 & 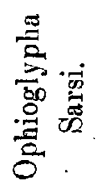 & 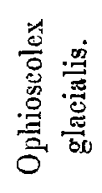 & 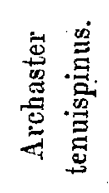 & 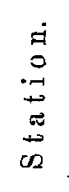 & $\begin{array}{l}\dot{0} \\
\stackrel{0}{0} \\
\stackrel{0}{0}\end{array}$ & 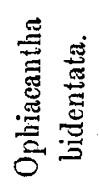 & 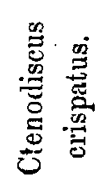 & 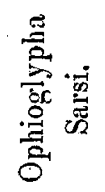 & 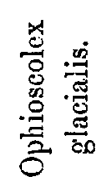 & 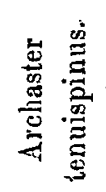 \\
\hline$S$ & 65 & + & + & $\ldots . .$. & $\ldots \ldots$ & + & 38 & $5 S_{\frac{1}{2}}$ & + & + & + & + & + \\
\hline 9 & 61 & + & $\ldots \ldots$ & + & $\ldots . .$. & + & 39 & 61 & + & + & + & + & + \\
\hline 10 & 58 & + & + & $\ldots . .$. & $\ldots . .$. & ....... & 40 & $55 \frac{1}{3}$ & + & ....... & $\ldots . .$. & + & + \\
\hline 11 & 55 & + & + & $\ldots . .$. & $\ldots . .$. & $\ldots \ldots$ & 41 & $55^{2}$ & + & + & $\ldots .$. & + & + \\
\hline 12 & 60 & $\ldots \ldots$ & + & $\ldots .$. & $\ldots \ldots$ & $\ldots . .$. & 42 & 55 & + & + & ...... & + & ...... \\
\hline 13 & 60 & + & ....... & $\ldots \ldots$ & $\ldots .$. & $\ldots . .$. & 43 & $67 \cdot \frac{1}{2}$ & + & + & + & + & + \\
\hline 14 & $5 S$ & + & + & + & $\ldots . .$. & $\ldots \ldots$. & 44 & 72 & + & + & + & + & + \\
\hline 15 & 60 & + & + & + & $\ldots .$. & $\ldots \ldots$ & 45 & 82 & + & + & + & + & + \\
\hline .16 & $5 S_{\frac{1}{2}}$ & + & + & + & ....... & ....... & 46 & 88 & + & + & ...... & + & + \\
\hline 17 & $54 \frac{1}{2}$ & + & + & + & $\ldots .$. & ........ & 47 & 87 & + & + & + & + & + \\
\hline 18 & .55 & + & $\ldots \ldots$ & + & $\ldots . .$. & ....... & 48 & 78 & + & + & + & + & + \\
\hline 19 & 54 & + & + & $\ldots \ldots$ & $\ldots \ldots$ & $\ldots \ldots$. & 49 & 69 & + & + & + & + & + \\
\hline 20 & 51 & + & + & + & $\ldots \ldots$. & $\ldots \ldots$ & 50 & $\check{\partial} 0$ & + & + & ...... & ....... & + \\
\hline 21 & $52 \frac{1}{2}$ & ....... & + & + & ....... & + & 51 & 47 & + & ....... & $\ldots .$. & + & + \\
\hline 22 & $59 \frac{1}{2}$ & + & + & + & $\therefore . .$. & $\ldots .$. & 52 & 44 & + & ....... & $\ldots . .$. & + & + \\
\hline 23 & $66 \frac{1}{2}$ & + & + & + & ....... & ....... & .53 & 49 & + & + & $\ldots \ldots$ & + & + \\
\hline 24 & 77 & + & + & + & + & + & 54 & 51 & + & + & + & + & + \\
\hline .25 & 68 & + & + & + & + & + & 55 & $51 \frac{1}{2}$ & $x$. & + & + & + & + \\
\hline 26 & S3 & + & + & + & + & + & 56 & อ1 & + & + & + & + & + \\
\hline 27 & 83 & + & + & + & + & + & 57 & 70 & + & + & ........ & + & + \\
\hline 28 & $84 \frac{1}{2}$ & + & $t^{\prime}$ & + & ....... & + & 58 & 70 & + & + & + & ....... & ...... \\
\hline 29 & $75 \frac{1}{2}$ & + & + & + & $\ldots . .$. & + & 59 & 50 & + & + & + & + & + \\
\hline 30 & 76 & $\ldots .$. & ....... & + & $\ldots \ldots$ & $\ldots \ldots$ & 60 & 56 & + & + & + & + & + \\
\hline 31 & 66 & + & + & + & $x$ & + & 61 & $5 \check{0}$ & + & + & + & + & + \\
\hline .32 & $74 \frac{1}{2}$ & + & + & + & ....... & + & 62 & 57 & + & + & + & + & + \\
\hline 33 & $68 \frac{1}{2}$ & + & ........ & + & $\ldots$ & + & 63 & 56 & + & + & + & + & + \\
\hline 34 & 60 & + & + & + & + & + & 64 & 61 & + & + & + & + & $\ldots . .$. \\
\hline 35 & 60 & + & + & ....... & + & + & 65 & 77 & + & + & ....... & + & + \\
\hline 36 & $5 \tilde{~}$ & + & + & ........ & + & + & 66 & 55 & + & + & $\ldots \ldots$ & + & + \\
\hline 37 & 54 & + & + & + & $\ldots \ldots$ & + & 67 & 59 & + & + & & ....... & + \\
\hline
\end{tabular}




\begin{tabular}{|c|c|c|c|c|c|c|c|c|c|c|c|c|c|}
\hline 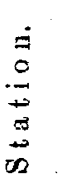 & $\begin{array}{l}\dot{0} \\
\stackrel{\vec{\theta}}{0} \\
\ddot{\theta}\end{array}$ & 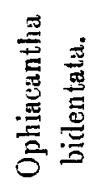 & 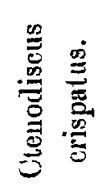 & 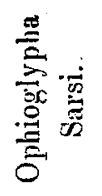 & 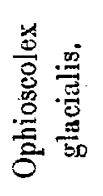 & 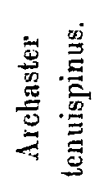 & $\begin{array}{l}\dot{\Xi} \\
\stackrel{\Xi}{\Xi} \\
\stackrel{\Xi}{\Delta} \\
\vec{U}\end{array}$ & $\begin{array}{l}\dot{\Xi} \\
\stackrel{\Delta}{\Delta} \\
\ddot{a}\end{array}$ & 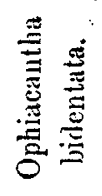 & 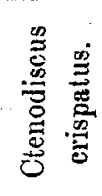 & 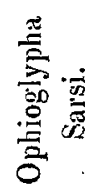 & 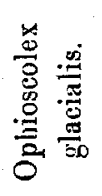 & 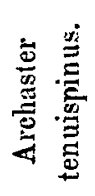 \\
\hline 68 & 75 & + & + & + & $\ldots \ldots$ & + & 76 & $78 \frac{1}{2}$ & ....... & $\ldots$ & + & $\ldots . .$. & ....... \\
\hline 69 & 66 & + & + & + & + & $\ldots \ldots$ & 77 & 76 & + & $\ldots . .$. & + & $\ldots \ldots$ & ....... \\
\hline 70 & 75 & + & + & + & + & ....... & 78 & 76 & + & $\ldots . .$. & + & $\ldots \ldots$ & ....... \\
\hline 71 & 85 & + & + & $\ldots \ldots$ & ....... & $\ldots . .$. & 79 & 77 & + & $\ldots \ldots$ & $\ldots . .$. & + & ....... \\
\hline 72 & 94 & + & + & ....... & ...... & ...... & 80 & $75 \frac{1}{2}$ & + & $\ldots .$. & $\ldots . .$. & + & ....... \\
\hline 73 & $76 \frac{1}{2}$ & + & + & $\ldots \ldots$ & $\ldots \ldots$ & ....... & 81 & 73 & + & $\ldots \ldots$ & + & + & ....... \\
\hline 74 & 70 & + & + & + & + & ...... & 82 & $73 \frac{1}{2}$ & + & $\ldots \ldots$ & + & + & ....... \\
\hline 75 & 76 & + & $\ldots \ldots$ & + & + & .... .. & 83 & 69 & + & ....... & + & + & + \\
\hline
\end{tabular}

Nog behoort tot de hier zeer algemeen voorkomende Echinodermen Trochostoma boreale. Dat deze species slechts 33 maal werd verzameld is dááraan toe te schrijven, dat de zwabbers, die, zooals boven vermeld, zeer dikwijls nitsluitend werden aangewend, ten eenenmale ongeschikt waren om deze dieren vast te houden en boven te brengen, zoodat deze zeer mogelijk op een veel grooter aantal plaatsen voorkomen, dan ik kan constateeren. Dat zulks zeer aannemelijk is, blijkt uit het feit, dat van de $41 \mathrm{keer}$ dat een dreg gebruikt werd, de genoemde Holothurie 25 malen aanwezig was, en dat wel gewoonlijk in niet weinige exemplaren. Des te meer is het daarom ook te verwonderen, dat door de Zweden dit hier werkelijk zeer algemeene dier slechts op één enkel station in de Karazee werd aangetroffen, namelijk op $70^{\circ} 45^{\prime} \mathrm{N}$. B. en $61^{\circ} \mathrm{O}$. L.

StuxвerG, die terecht beweert dat, om de fauna van een streek goed te begrijpen, het niet genoeg is om te weten welke soorten er in die streek voorkomen en welke niet, maar dat men daartoe ook moet achtgeven op den relatieven rijkdom an individuen der verschillende soorten, neemt voor de Siberische IJszee een 20tal dierformatiën aan, waaronder hij grootere of kleinere. nitgestrektheden terrein verstaat, waarbinnen een of eenige weinige soorten in verreweg het grootste aantal voorkomen, terwijl de overige soorten, die hen vergezellen, ieder voor zich zeer arm aan individuen zijn.

Uit de opgaven blijkt, dat $\delta$ van deze dierformatiën ook in de eigenlijke Karazee, tusschen Nova-Zembla en de Westkust van het Samojedenschiereiland Jalmal, voorkomen; dit zijn namelijk: de Asterias-, Ctenodiscus-, Ophiocantha-, Reticulipora-, ArchasterCtenodiscus-, Ophiacantha-Archaster-en de Yoldiaformatie.

Hiervan werd evenwel de A sterias-formatie an de monding der Karagolf, vrij dicht onder de kust, en op slechts 48 vaâm aangetroffen; de O p hi ogly pha-formatie vond hij op 100 vaâm aan de kust van Nova-Zembla, iets benoorden den oostelijken ingang van den Matotschkinshar; eveneens dicht onder de Oostkust van genoemd eiland kwam de R eticulipora. formatie op 40 tot 125 vaâm voor, terwijl eindelijk de Yoldia-formatie op de zeer geringediepte van 3-20 vaâm, dicht onder de Jalmalkust werd aangetroffen.

Het voorkomen dezer vier dierformatiën kon ik dan ook op het door mij onderzochte terrein nergens constateeren. Anders was het gesteld met de vier overige der acht genoemde formatiën, die op verschillende Stations voorkwamen, waarbij ik er evenwel op wil wijzen, dat zij slechts. in de minderheid der gevallen zeer duidelijk waren, en niet zelden in elkander overgingen, terwijl op een aantal stations in 't geheel geen sprake kon zijn van dierformatiën in den zin, waarin Stuxberg dit bedoelt, daar er geen diervorm was an te wijzen, die in buitengewone mate de. overigen in individuen-aantal overtrof.

Als een nieuwe, niet door Stuxberg vermelde formatie, meen ik die van Pecten grönlandicus te moeten vermelden. Deze Lamellibranchiat kwam op de stations 22 
en 23 inderdaad in ontzaggelijk aantal voor, en liet in dat opzicht alle haar vergezellende dieren ver achter zich.

De voornaamste soorten dezer op $59 \frac{1}{2}$ en $66 \frac{1}{2}$ vaâm diepte aangetroffen formatie zij̣n: M u nnopsistypica, Nereis zonata, Pectinaria hyperborea, Phascolosoma (boreale?), Trochostoma boreale, Ophiacantha bidentata, Ophioglypha Sarsi en Ctenodiscus crispatus.

Het volgende lijstje geeft aan, op welke stations en op welke diepten de vijf bedoelde dierformatiën door.mij werden aangetroffen:

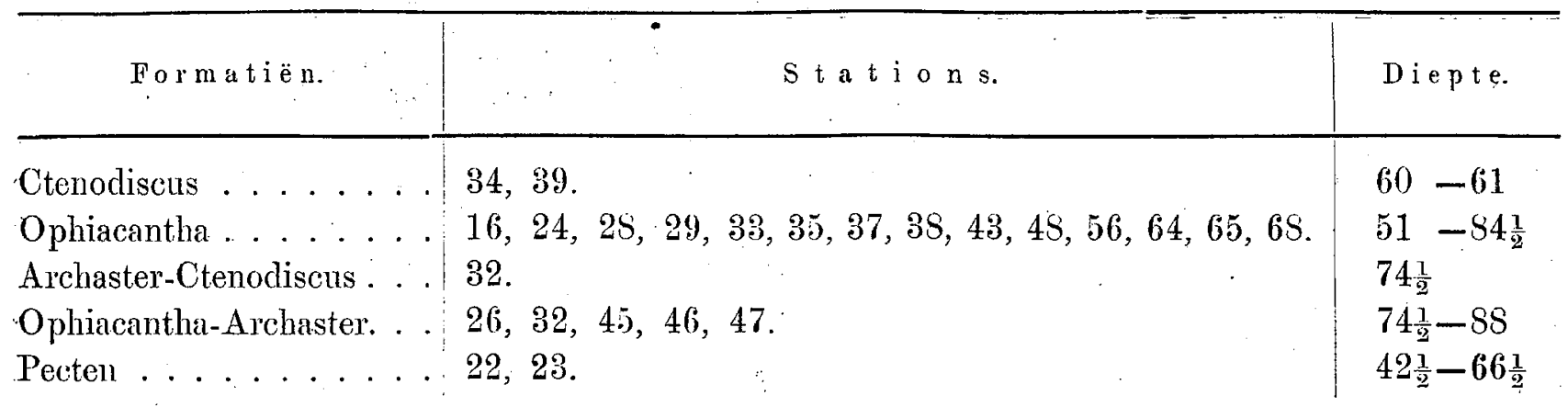

Ten slotte wil ik hier nog ecnige woorden in 't midden brengen over een ook elders reeds in twijfel getrokken stelling van STuxberG, dat namelijk Nova-Zembla een bepaalde grens zou vormen voor het voorkomen van een groot aantal diersoorten, die ten westen of ten oosten van dit eiland op den zeebodem worden aangetroffen 1).

Wat $n u$ in de eerste plaats aangaat de dieren, die wel west- maar niet noordwaarts van NovaZembla voorkomen, en S'ruxbirc geeft een aantal zulke vormen op, zoo wil ik doen opmerken, dat hiervan twee der meest typische en op de Westkust algemeen voorkomende door mij ook in de Karazee worden aangetroffen, namelijk $O p h$ iopholis a cule at a op $71^{\circ} 17^{\prime} \mathrm{N}$. B. $64^{3} 6^{\prime}$ O. L. en Crangon boreas op $70^{\circ} \mathrm{S}^{\prime} \mathrm{N}$. B. $64^{\circ} 6^{\prime}$ O. L. en op $71^{\circ} 34^{\prime}-\mathrm{N} . \mathrm{B} .64^{\circ} 38^{\prime} \mathrm{O}$. L. Bovendien komen, zooals de Zweedsche onderzoeker zelf alangeeft, verschillende der genoemde :soorten slechts op de kusten van Groenland en niet verder oostelijk voor, en het is toch $\mathrm{m}$. i. wel wat ver getrokken, het ontbreken van zulke soorten ook ten oosten van Nova-Zembla aan te voeren als een bewijs daarvan, dat dit eiland een natuurlijke diergeographische grens uitmaakt.

Vestigen wij in de tweede plaats de aandacht op die vormen, die wel ten oosten, maar tot nu toe niet ten westen van Nova-Zembla werden gevonden, dan blijft het ontegenzeggelijk waar, dat er een aantal zijn aan te wijzen, die wel in de Siberische IJszee, maar niet in de Barentszee werden gevonden; maar evenzeer is het waar, dat meerdere dezer soorten ook in de Karazee ontbreken en reeds veel verder oostwaarts de westgrens hunner verspreiding vinden. Andere, voor de Siberische IJszec zeer typische, westwaarts van Nova-Zembla daarentegen ontbrekende of althans nog niet gevonden soorten, vinden het maximum harer verspreiding eveneens ver oostelijk en behooren in de eigenlijke Karazee eerder tot de zeldzame dan tot de veelvuldig voorkomende dieren. Een sprekend voorbeeld hiervan troffen wij boven (p. 46) in I d o tea e n to mo n aan, die op de 'Siberische kusten, b.v. onder den 140stem lengtegraad, in tallooze, in de Karazee daarentegen in slechts enkele exemplaren en op de Oostkust van. Nova-Zembla in 't geheel niet werd aangetroffen. Dergelijke gevallen brengen ons tot de gevolgtrekking, dat voor deze dieren de omstandigheden, die hun versprciding beperken of beletten, niet eerst bij Nova-Zembla, maar reeds verder oostelijk optreden.

Paranthura arctica, door Sruxbera opgegeven als ook ten westen van Nova-Zembla

1) 1. c. p. 769 . 
en Franz-Josephland niet voorkomende, werd door Dr. Max WEBer gedurende de reis der 》Willem Barents《 in 1881 in de Barentszee en in de zee tusschen Scandinavie en Spitsbergen aangetroffen ${ }^{2}$ ).

Niet onwaarschijnlijk komt het mij voor, dat bij onze nog alles behalve volledige kennis der: arktische zeeën, de bedoelde stelling van Sтuхвев. wel wat voorbarig is, en dat een voortgezet onderzoek dezer streken nog cen aantal vormen aan het licht zal brengen, waarvoor de door hem bedoelde grensscheiding zal blijken niet te gelden.

Er is nog een ander feit, dat mij nog meer versterkt in mijn meening, dat Nova-Zembla geen natumlijke dier-geographische grens vormt, cen feit dat volgt uit hetgeen wij in de laatste jaren door de talrijke onderzoekingen van den Zweedschen botanicus KJnLLman zijn te weten gekomen van de Algenvegetatie der Noord-Europeesche en Noord-Aziatische kusten. In een reeks van bijdragen toch ${ }^{2}$ ) behandelt genoemde onderzoeker de Algenflora van de Barentszee en de Karazee, benevens die der kusten van Siberië, en hieruit blijkt, dat ten minste voor de verspreiding der. zeealgen Nova-Zembla volstrekt geen grens vormt; integendeel spreekt Kueriman zich aan het. einde van het laatstgenoemd opstel zeer duidelijk in de volgende bewoordingen uit: 》Het westelijk gedeelte der Siberische IJszee, ten minste tot Kaap Tscheljuskin toe, moet men zonder twijfel beschouwen als te behooren tot het Spitzbergsch gebied der zeealgenflora, ofschoon zijn vegetatie armer aan individuen en soorten is. De Algenflora in het oostelijk gedeelte dezer zee stemt. eveneens in zekere mate met die der kusten van Spitsbergen en Nova-Zembla overeen, maar bezit in de samenstelling van zijn Laminaria-vegetatie een element, dat aldaar vreemd is, en wijst. op een verband met de Algenvegetatie in de noordelijke declen van den Stillen Oceaan ${ }^{8}$ ). Wanneer wij dus eenerzijds zien, dat de zeealgenflora ten oosten van Nova-Zembla a. h. w. een voortzetting is ran dic ten westen daarvan, dan kan het toch dunkt mij anderzijds ook niet. waarschijnlijk zijn, dat dit eiland als dier-geographische grens een belangrijke rol zou spelen, daar toch èn de verspreiding der Algen èn die der Evertebrata der poolzeeën voor een groot deel door dezelfde invloeden worden beheerscht.

Ook wil ik er hier nog op wijzen, dat de bodem ten westen en ten oosten van Nova-Zembla, cnkele locale verschillen daargelaten, toch over 't algemeen een belangrijke overeenkomst vertoont. Immers bij een vergelijking der tabellen van de dreggingen, door de »Willem Barents verschillende tijden en op verschillende plaatsen in de Barentszee gedaan ${ }^{4}$ ), met die, welke door StuxberG en mij voor de Karazee worden gegeven, blijkt dat in beide gevallen leembodem een groote rol speelt en het veelvuldigst wordt angetroffen, terwijl op zeer vele plaatsen rood ijzeroxyde in niet onbelangrijke hoeveetheid in den bodem voorkomt. Hierbij komt nog, dat zoowel de Barents- als de Karazee zich kenmerkt door cen betrekkelijk geringe diepte, zoodat men ze gezamenlijk zou kumnen beschouwen als één plateau, waarop Nova-Zembla zich dan als een terreinverheffing voordoet. Al deze punten van overeenkomst zouden misschien ook als argumenten kunnen worden aangevoerd voor het, bestaan van eene grootere gelijkheid der beide fauna's ten westen en ten oosten ván Nova-Zembla dan onze nu nog ontoereikende kennis schịnt aan te duiden.

1) Verslag over de zoölogische onderzoekingen gedurende de 4e reis der "Willem Barents/, door Dr. Max WeBEr. Bijlage I van de "Verslagen omtrent den vierden tocht van de "Willem Barents" naar de IJszee in den zomer van. 1881. Haarlem 1882."

2) F. R. KuEllman. Ueber die Algenvegetation des Murmanschen Meeres an der Westküste von Nowaja Semlja. und Waigatsch. Upsala 1877. Bidrag till künnedomen af Kariska hafvets Algregetation (Öfversigt af K. Svensk. Vet Akad. Förhandl. 34 : de årg (1877) no. 2, p. 3-20).

1. c. p. 229.

4) Vergelijk: Einleitende Bemerkungen zu den naturwissenschaftlichen Ergebnissen des "Willem Barents" in das. nördliche Eismeer, von Prof. MAx WEBer - in: Bijdragen tot de Dierkunde, uitgegeven door het Genootschap "Natura Artis Magistra", 10e Afl. 1884 p. 1. 